September 2003 • NREL/SR-560-34864

\title{
Current Solutions: Recent Experience in Interconnecting Distributed Energy Resources
}

M. Johnson

Sentech Inc.

Bethesda, Maryland

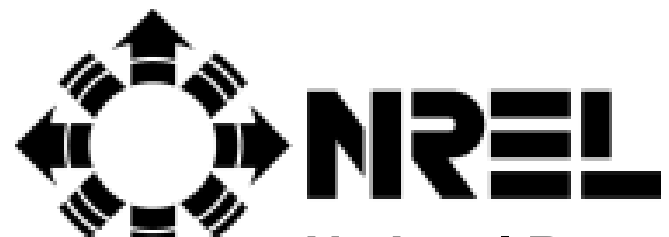

National Renewable Energy Laboratory

1617 Cole Boulevard

Golden, Colorado 80401-3393

NREL is a U.S. Department of Energy Laboratory

Operated by Midwest Research Institute $\bullet$ Battelle $\bullet$ Bechtel

Contract No. DE-AC36-99-G010337 


\section{Current Solutions: Recent Experience in Interconnecting Distributed Energy Resources}

M. Johnson

Sentech Inc.

Bethesda, Maryland

NREL Technical Monitor: Holly Thomas

Prepared under Subcontract No. KLAT-2-32611-01

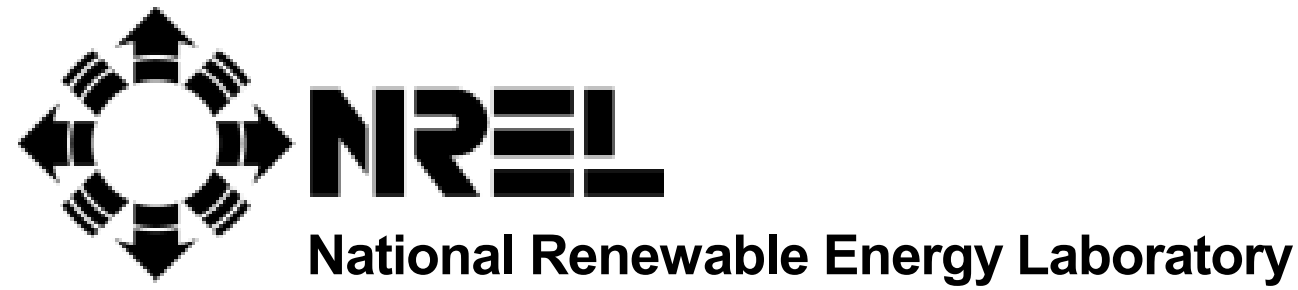

1617 Cole Boulevard

Golden, Colorado 80401-3393

NREL is a U.S. Department of Energy Laboratory

Operated by Midwest Research Institute • Battelle • Bechtel

Contract No. DE-AC36-99-G010337 


\section{NOTICE}

This report was prepared as an account of work sponsored by an agency of the United States government. Neither the United States government nor any agency thereof, nor any of their employees, makes any warranty, express or implied, or assumes any legal liability or responsibility for the accuracy, completeness, or usefulness of any information, apparatus, product, or process disclosed, or represents that its use would not infringe privately owned rights. Reference herein to any specific commercial product, process, or service by trade name, trademark, manufacturer, or otherwise does not necessarily constitute or imply its endorsement, recommendation, or favoring by the United States government or any agency thereof. The views and opinions of authors expressed herein do not necessarily state or reflect those of the United States government or any agency thereof.

Available electronically at http://www.osti.gov/bridge

Available for a processing fee to U.S. Department of Energy and its contractors, in paper, from:

U.S. Department of Energy

Office of Scientific and Technical Information

P.O. Box 62

Oak Ridge, TN 37831-0062

phone: 865.576 .8401

fax: 865.576.5728

email: reports@adonis.osti.gov

Available for sale to the public, in paper, from:

U.S. Department of Commerce

National Technical Information Service

5285 Port Royal Road

Springfield, VA 22161

phone: 800.553.6847

fax: 703.605.6900

email: orders@ntis.fedworld.gov

online ordering: http://www.ntis.gov/ordering.htm 


\section{Acknowledgements}

Sentech would like to thank the many members of the distributed energy resources and utility communities who took valuable time to answer its repeated inquiries regarding their interconnection experiences.

In addition, Sentech would like to thank the Department of Energy and the National Renewable Energy Laboratory for providing guidance and funding for this study. Specifically, it would like to thank Joseph Galdo, former program manager of the Department of Energy's Distributed Power Program, and Richard DeBlasio and Holly Thomas of the National Renewable Energy Laboratory for lending their leadership and expertise to this effort. 


\section{Nomenclature}

$\begin{array}{ll}\text { AEC } & \begin{array}{l}\text { Alternative Energy Corporation } \\ \text { distributed energy resource(s) }\end{array} \\ \text { DER } & \text { Institute of Electrical and Electronics Engineers } \\ \text { IEEE } & \text { Los Angeles Department of Water and Power } \\ \text { LADWP } & \text { Pacific Gas and Electric } \\ \text { PG\&E } & \text { Pharmaceutical Sourcing Group - Americas } \\ \text { PSGA } & \text { photovoltaic(s) } \\ \text { PV } & \text { Southern California Edison } \\ \text { SCE } & \text { San Diego Gas \& Electric } \\ \text { SDG\&E } & \text { standard interconnection requirements } \\ \text { SIR } & \text { Underwriters Laboratories }\end{array}$




\section{Executive Summary}

Distributed energy resources (DER) are small, modular power-generating or energy storage technologies that can be combined with energy management systems and used to improve the operation of electricity delivery systems. ${ }^{1}$ These technologies include fuel cells, solar photovoltaics, wind turbines, microturbines, reciprocating engines, Stirling engines, batteries, and other energy storage systems.

During the past few years, interest in distributed energy has increased because of technological advances in distributed generation technologies, electricity costs that can be competitive with the utility industry's, the expansion of competition within the electric utility industry, and an increased need for reliable and high-quality power. Despite the increased interest in distributed energy technologies, several factors have prevented them from gaining a larger share of the electricity market. Among these factors are difficulties interconnecting DER with the grid.

During the summer of 2002, Sentech was contracted through the Department of Energy and the National Renewable Energy Laboratory to catalogue selected real-world technical experiences of utilities and customers that have interconnected distributed energy assets with the grid. This study was initiated to assess the actual technical practices for interconnecting distributed generation and had a particular focus on the technical issues covered under the Institute of Electrical and Electronics Engineers (IEEE) $1547^{\mathrm{TM}}$ Standard for Interconnecting Distributed Resources With Electric Power Systems.

Over the course of 4 months, Sentech interviewed 35 utilities, distributed energy manufacturers, system integrators, and electricity customers to ascertain which issues are driving interconnection today. Twenty-one of these interviews (10 with utilities and 11 with distributed energy manufacturers, installers, and customers) are included as case studies in this report.

These interviews revealed numerous interconnection issues at the technical, regulatory, and business levels.

Of the technical issues, the primary concern for utilities was the potential for DER to continue to energize the utility system sections with which they are interconnected after a fault and cause damage to the grid or safety issues for linemen. (This situation, sometimes called "islanding," occurs when an electric generator fails to immediately disconnect from the grid during a fault condition or other event during which there would otherwise be no energy on that portion of the local electric power system.) Utilities also raised concerns about the difficulties surrounding pre-certification of power electronics, the potential effects of base load DER penetration on the grid, and how DER will interact with networked distribution systems.

\footnotetext{
${ }^{1}$ DER also include energy management, which was not considered for this report because it is not affected by interconnection issues.
} 
Nontechnical issues utilities were concerned about included the need to educate customers about the issues associated with interconnecting distributed energy with the grid. They were also concerned that interconnection standards that were incompatible with the requirements of their particular transmission and distribution systems might be imposed at the state or national level.

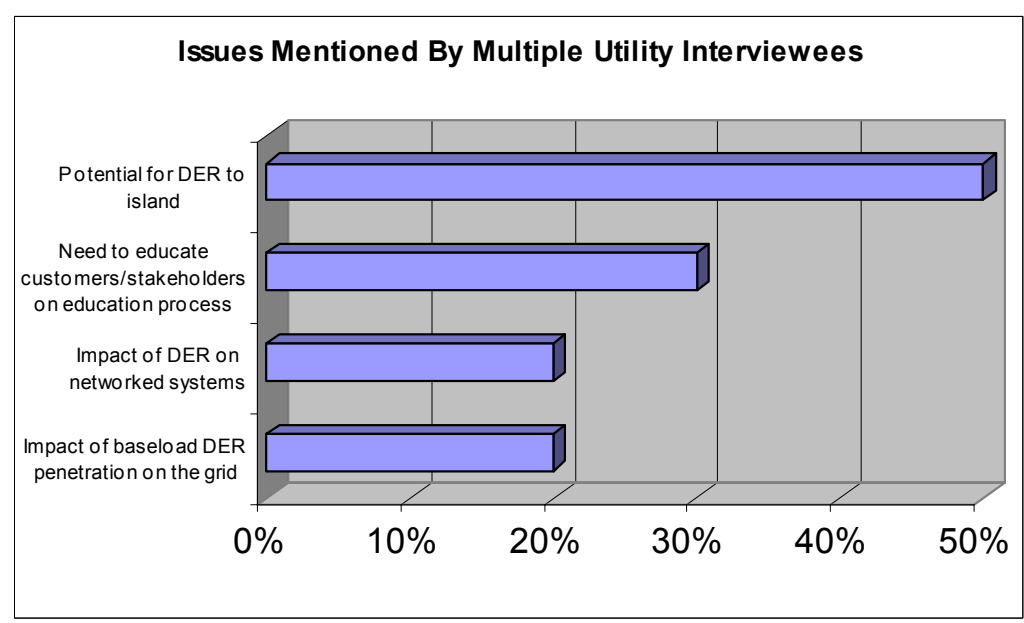

Figure i. Issues mentioned by multiple utility interviewees

Customer-side interviewees had several technical concerns. Among these was the concern that some interconnection requirements appear to be either unjustifiable or unrealistic from a technical perspective or too costly to be met in an economically viable fashion. Customer-side interviewees provided a variety of examples of interconnection requirements they found to be undue or excessive. They also raised concerns that DER were being asked to meet a power quality standard that utilities do not require their own generators or other loads to meet and that utilities were placing performance requirements on power electronics that were difficult to meet or set point requirements that were difficult to identify. Another issue for distributed energy installers and customers was the incidence of "nuisance trips," in which a DER is forced to trip offline because of a momentary disturbance on the grid.

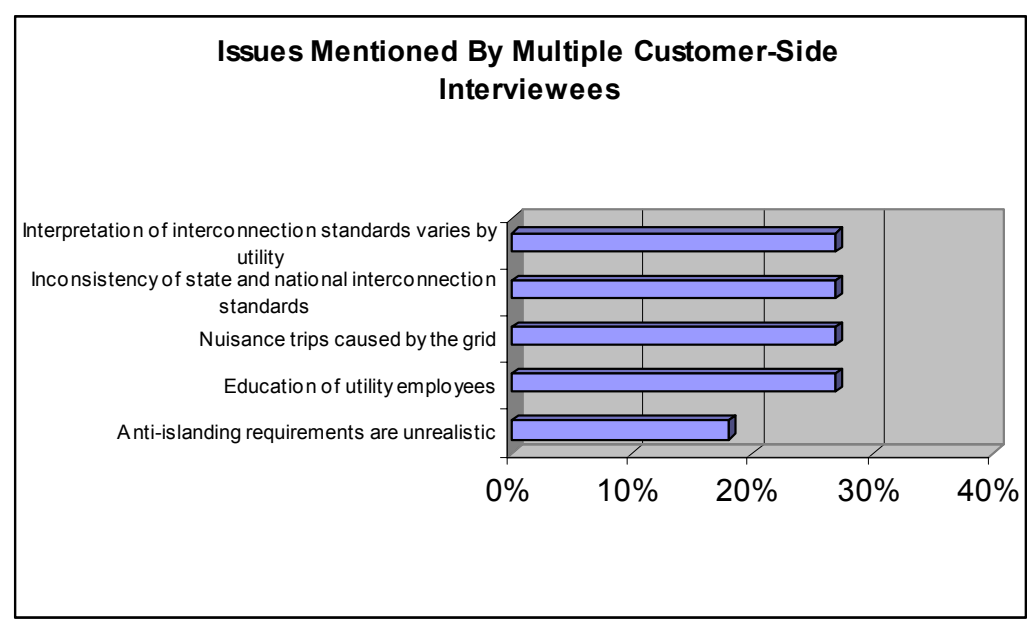

Figure ii. Issues mentioned by multiple customer-side interviewees

Interviewees on the customer side of the meter also raised a variety of business and regulatory issues - many more than utilities did. Concerns included what was believed to be a lack of knowledge about DER issues within utilities, varying interpretations of interconnection standards by utilities, and the inconsistency of state and national interconnection standards. The prevalence of nontechnical issues among customer-side interviewees indicates that business and regulatory barriers to interconnection still play an important part in hindering the development of the market for distributed energy technologies. 
Sentech's analysis indicates that, although much progress has been made in recent years to ease the interconnection process, significant perception gaps remain among the key players and will be difficult to bridge. These gaps revolve around the potential effect of distributed generation on the grid and how best to mitigate that effect.

All the utilities interviewed have established interconnection procedures. However, many are reluctant to actively support the interconnection of DER with the grid if they perceive any increased liability resulting from safety concerns about the interconnection or the generator. This increased liability threshold may be an unreachable standard for any DER to meet.

Based on the comments from this survey, it appears the DER community tends to view utilities' reluctance to interconnect as an anticompetitive attitude toward new market players. Thus, this survey indicates that the drive of the DER industry to enter new markets and create new business is colliding with the conservative aspects of the utility industry and the general reticence of utilities to jeopardize the integrity of their systems.

Regulatory agencies such as state public utility commissions and the Federal Energy Regulatory Commission as well as organizations such as the IEEE and Underwriters Laboratories have recognized the need for standardization and regulation relating to DER interconnection and have begun to propose solutions. Although these standards provide a base and work in this area is ongoing, the interviews indicated there is still much work to be done before standards that satisfy the needs and desires of all interested parties can be developed. Needs include more detailed national interconnection standards (which have now been defined under the IEEE 1547 effort) and an increased focus on reconciling differing interconnection standards to a more coherent baseline to which all parties can adhere. 
Sentech's interviews and assessments revealed several common issues regarding interconnection.

\section{Issues}

Issue: The primary concern of utilities is safety and system protection, but utilities can provide only limited real-world examples of how the safety or integrity of their systems has been adversely affected by DER.

Issue: DER manufacturers and customers often view interconnection requirements as unjustified and anticompetitive, but they have difficulty proving these claims.

Issue: IEEE 1547 is a key piece to the puzzle and represents consensus building of all parties concerned, but there is increasing demand for more detailed interconnection requirements and procedures that can help standardize interconnection requirements nationwide. This need will be answered, in part, by the supporting standards and guides to 1547-P1547.1, P1547.2, and P1547.3and a revision of IEEE 1547 with supporting research and testing.

Issue: Education about interconnection and DER issues is a common goal of utilities and distributed generation customers/manufacturers. However, there is a difference of opinion about where education efforts should be focused.

Issue: Both sides recognize dialogue to be an important tool in the design of interconnection standards because it builds stakeholder buy-in and a more complete standard than other methods of development. 


\section{Table of Contents}

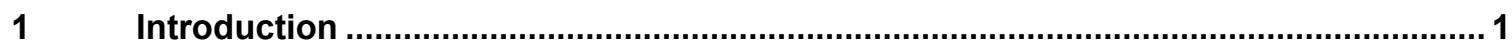

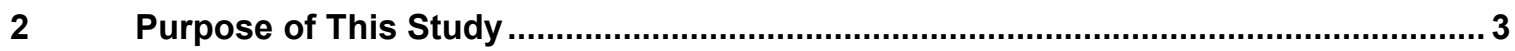

$3 \quad$ Summary of Interview Findings

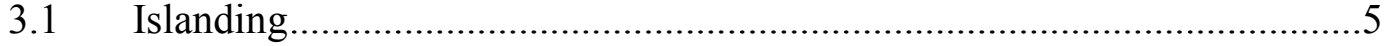

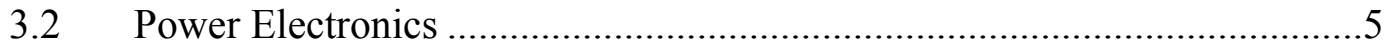

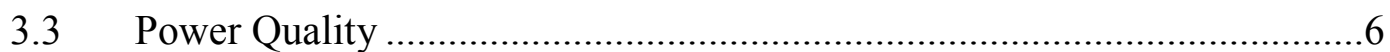

3.4 Other Technical Interconnection Issues................................................6

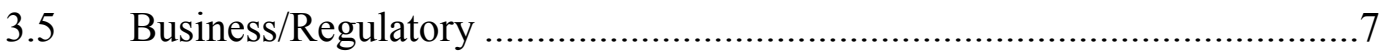

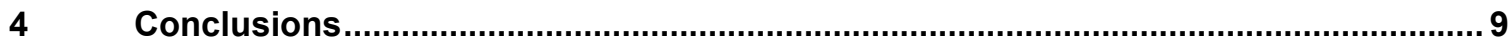

4.1 The Primary Concern of Utilities Is Safety and System Protection.............9

4.2 DER Manufacturers and Customers Often View Interconnection Requirements as Unjustified and Anti-Competitive, but They Have Difficulty Proving These Claims ...........................................................10

4.3 IEEE 1547 Is a Key Piece to the Puzzle, but There Is Increasing Demand for More Detailed Interconnection Procedures That Can Help Standardize Interconnection Requirements Nationwide..................10

4.4 Education About Interconnection and DER Issues Is a Common Goal of Utilities and Distributed Generation Customers/Manufacturers, but There Is a Difference of Opinion About Where Education Efforts Should Be Focused ..............................................................................11

4.5 Dialogue Is a Useful Tool in the Design of Interconnection Standards ....12

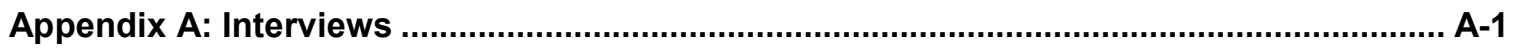

A.1 Methodology ............................................................................. A-1

A.2 Description of Issue Types.................................................... A-1

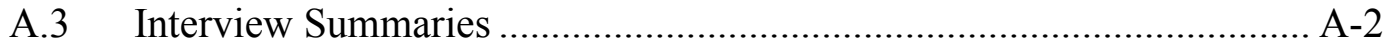

A.3.1 Utility Interviews ...................................................... A-3

Alliant Energy .................................................................. A-3

Anonymous Midwestern Utility .......................................... A-6

Central Hudson Gas \& Electric.............................................. A-9

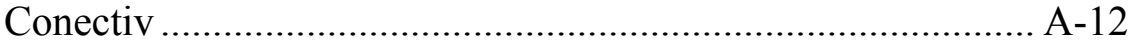

Idaho Power ................................................................ A-16

Los Angeles Department of Water and Power ....................... A-20

Long Island Power Authority.............................................. A-22

Pacific Gas and Electric ...................................................... A-26

San Diego Gas \& Electric ................................................... A-29

Southern California Edison.................................................. A-31 
A.3.2 Customer/Manufacturer/Developer Interviews ..................... A-34

Alternate Energy Corp. ........................................................... A-34

Bergey Windpower ............................................................ A-36

BP Solar ...................................................................... A-39

Capstone Turbine ............................................................ A-41

Cordis Corp.............................................................. A-44

Cummins Engine.................................................................. A-46

Hess Microgen .................................................................. A-49

Ingersoll-Rand Energy Systems.......................................... A-53

Offshore Services Ltd. ........................................................ A-55

Pharmaceutical Sourcing Group - Americas.......................... A-57

PowerLight Corp.......................................................... A-59

Appendix B: Tables Summarizing Interconnection Requirements and Experience........... B-1

Appendix C: Interviews Not Included in Case Write-Ups .................................................. C-1

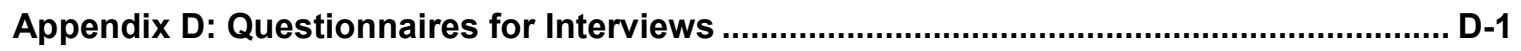




\section{List of Figures}

Figure 1. Issues Mentioned by Multiple Customer-Side Interviewees .......................4

Figure 2. Issues Mentioned by Multiple Utility Interviewees .....................................4

\section{List of Tables}

Table A-1. San Diego Gas \& Electric Distributed Generation Installations.............. A-29

Table B-1. Selected Technical Distributed Generation Interconnection

Requirements of Interviewed Utilities .................................................. B-1

Table B-2. Major Technical, Business, and Regulatory Issues Encountered by

Utilities During Distributed Generation Interconnection ......................... B-6

Table B-3. Major Technical, Business, and Regulatory Issues Encountered by Customers and Manufactures During Distributed Generation

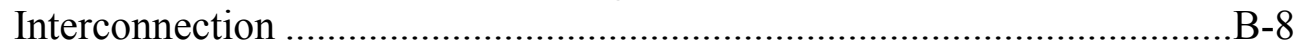

Table C- 1. Interviews Not Included in Case Write-Ups .............................................. 


\section{Introduction}

Distributed energy resources (DER) are small, modular power-generating and energy storage technologies that can be combined with energy management systems and used to improve the operation of the electricity delivery system. These technologies include fuel cells, solar photovoltaics (PV), wind turbines, microturbines, reciprocating engines, Stirling engines, batteries, and other energy storage systems.

Over the past few years, distributed energy options have gained prominence because of technological advances and cost reductions in the technologies, electricity costs competitive with the utility industry's, the expansion of competition within the electric utility industry, some widely reported power disruptions and price spikes, and an increased need for reliable and high-quality power. Consumers are now more aware of their energy choices and how distributed energy options can increase their range of choices.

Despite increasing interest in distributed energy technologies, there has not been a large deployment of these technologies by electric utilities or electricity consumers. Several factors have prevented these technologies from gaining a larger share of the electricity market.

- Cost and reliability are still issues for many of these technologies.

- Although awareness has increased, there is still a lack of understanding about these technologies among the general public.

- Many potential customers, especially residential users, are unfamiliar with the option of on-site power generation.

- Regulatory schemes are sometimes not conducive to the growth of distributed generation because they add costly fees and regulations that negatively affect the economic viability of projects.

In addition, the difficulties associated with interconnecting DER with the grid may be acting as a roadblock to increased market growth for distributed generation technologies.

In 2000, the National Renewable Energy Laboratory and the Department of Energy completed a study that documented the nature of entry barriers to distributed energy technologies. This study, Making Connections: Case Studies of Interconnection Barriers and Their Impact on Distributed Power Projects, examined the experiences of 65 distributed generation customers and identified the types of technical, business, and regulatory barriers encountered during the interconnection processes of their projects. The study concluded that there were major technical, regulatory, and business barriers to the interconnection of distributed energy with the grid and made a series of recommendations to reduce those barriers. 
Since the completion of the Making Connections study, much has changed in the area of distributed generation interconnection. California, Texas, New York, and other states have implemented statewide interconnection standards that set performance targets for distributed energy and power electronics manufacturers. At the national level, the September 2002 affirmative vote and subsequent acceptance and publication of the Institute of Electrical and Electronics Engineers (IEEE) $1547^{\mathrm{TM}}$ Standard for Interconnecting Distributed Resources With Electric Power Systems is key toward establishing a national interconnection standard. This successful effort represents significant consensus building among all parties concerned. 


\section{Purpose of This Study}

The purpose of this study was to assess the status of interconnecting distributed generation with the utility grid. During the 3 years since the completion of Making Connections, additional DER systems have been installed, and customers, system integrators, manufacturers, and utilities have all gained experience in how to interconnect distributed generation with the grid. The primary goal of this survey was to document the technical approaches taken to interconnection during the past 3 years to determine what is working, where questions remain, and what needs improvement. Business and regulatory issues that arose during the process were also documented. 


\section{Summary of Interview Findings}

Over the course of 4 months, Sentech interviewed 35 entities - including utilities, distributed energy manufacturers, system integrators, and electricity customers - to ascertain which issues are driving interconnection today. Twenty-one case studies (10 with utilities and 11 with distributed energy manufacturers, installers, and customers) are included in this report.

These case studies are based on one or more interviews with individuals within an organization. Where necessary, information from these interviews was augmented with external research, particularly to further develop information relating to interconnection standards and requirements for individual utilities. Full summaries of each of these interviews are contained in Appendix A.

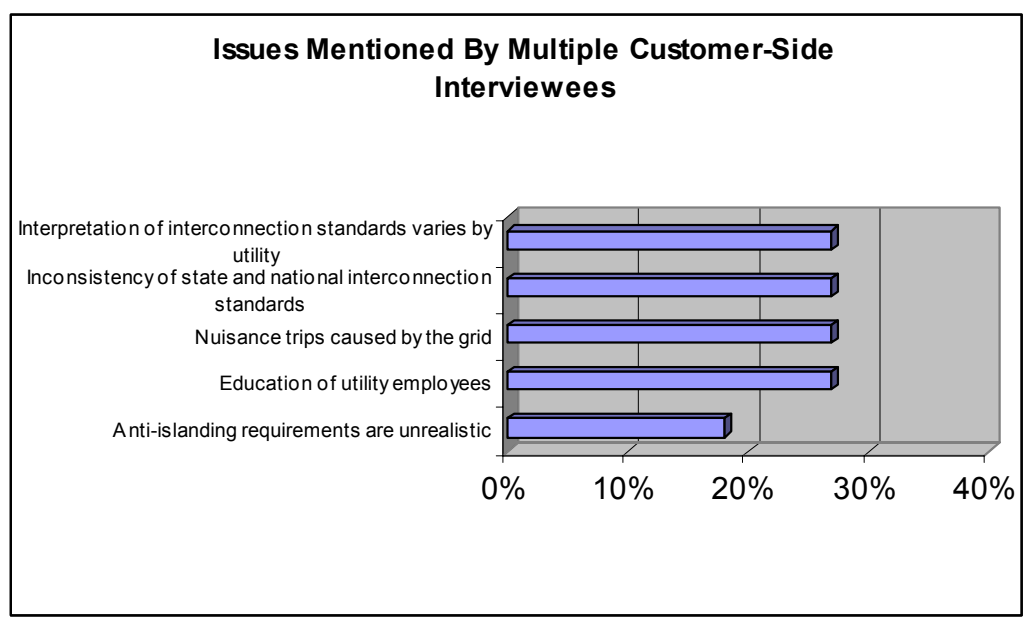

Figure 1. Issues mentioned by multiple customer-side interviewees

From these interviews, Sentech identified major trends and interconnection issues. The data were organized into five broad categories: islanding, power quality, power electronics, other technical issues, and business/regulatory issues.

This section of the report details the major issues raised in each category by utility and customer-side interviewees. Appendix B

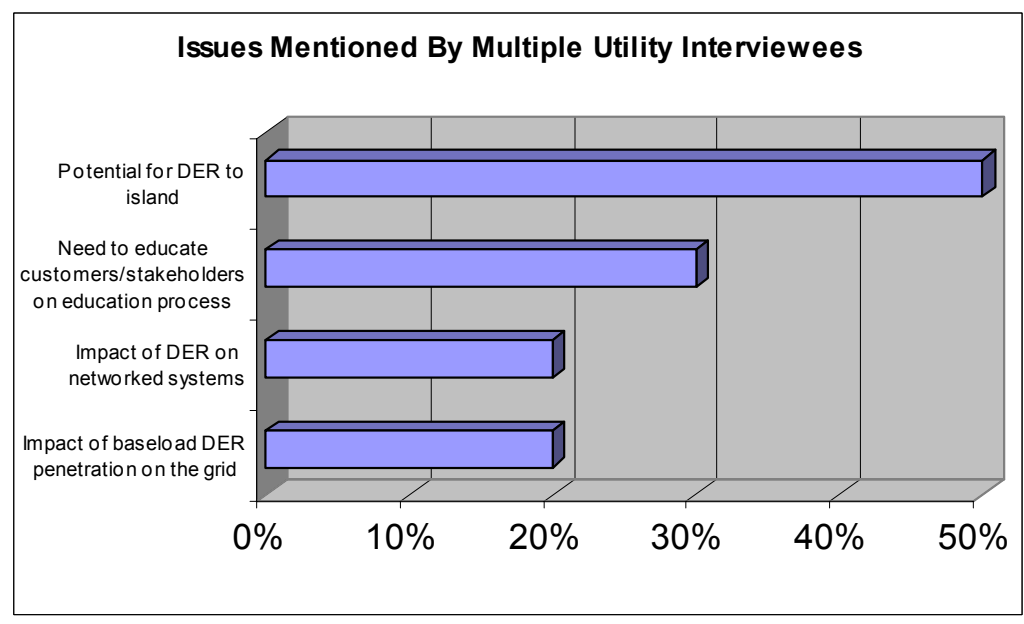

Figure 2. Issues mentioned by multiple utility interviewees contains tables that show which interviewees encountered which issues. 


\subsection{Islanding}

\subsubsection{Utilities}

There is a possibility DER could energize the sections of the grid to which they are connected after a fault, which could cause safety and reliability issues. (This situation, sometimes called "islanding," occurs when an electric generator fails to immediately disconnect from the grid during a fault condition or other event during which there would otherwise be no energy on that portion of the local electric power system.) This was the issue most frequently raised by utilities. Of the utilities interviewed, 50\% mentioned this issue specifically. For utilities, the chief concern with DER islanding is the potential of injury of a lineman during an outage from an islanding situation. Of the utilities interviewed, however, only one, Idaho Power, reported an actual case of a lineman being electrocuted because of an islanding incident involving a distributed generator.

\subsubsection{Customers/Manufacturers}

Several interviewees noted that utilities are placing an emphasis on ensuring that distributed energy does not island in a fault condition. Among the prominent islanding-related issues mentioned by manufacturers and customers was the concern that anti-islanding protections in IEEE and Underwriters Laboratories (UL) standards are predicated on laboratory testing rather than on real-world conditions, which may result in excessively stringent anti-islanding requirements that are difficult and costly to meet.

In addition, $18 \%$ of interviewees felt that utilities sometimes require excessive anti-islanding protections in the form of relays and other gear in an attempt to provide absolute safety for linemen, customers, and the system when the utilities can provide no evidence of actual situations in which lineman or system safety have been compromised by a distributed generation interconnection. Although the DER community does not dispute the necessity of anti-islanding and safety protections, it generally espouses the view that current protective requirements go beyond what is necessary to provide a reasonable level of protection while allowing DER to compete with other generation sources.

\subsection{Power Electronics}

\subsubsection{Utilities}

The only specific issue regarding power electronics that was noted by utilities was the risk to the customer or utility if equipment that is pre-certified loses that certification after installation. One example that was cited was an inverter that lost its pre-certification after a number of units had been installed on utility systems. In general, the utilities interviewed seemed to recognize the potential of pre-certification to enable the installation of DER. However, the utilities also viewed pre-certification with some wariness because they feel that the unique nature of each grid system makes it difficult to apply a single pre-certification standard across all systems. 


\subsubsection{Customers/Manufacturers}

For customers and manufacturers of distributed generation, there appeared to be two principal issues regarding power electronics. The first revolved around ensuring that power electronics have set points that comply with utility requirements because utilities sometimes do not provide information about what those set points need to be. The second concern of interviewees was the ability of power electronics to meet the performance testing requirements of utilities because these requirements were often difficult to meet.

\subsection{Power Quality}

\subsubsection{Utilities}

Regarding power quality, utilities noted a variety of issues. These included a need to better understand the overall effect of distributed generation on power quality, how to regulate and maintain voltage on the grid with distributed generation installed on the system, and the ability of distributed generation to regulate its own power quality when disconnected from the grid (utilities view this as a concern because the inability of distributed generation to regulate power quality could force customers back onto the grid).

\subsubsection{Customers/Manufacturers}

Although power quality issues were not a concern articulated by most of the customers and manufacturers interviewed, it was noted that it seemed inequitable that power generated by distributed generators must meet a standard of quality (the IEEE 519 standard) that utilities do not require of their own generators or of other loads on the system. Several interviewees also noted that power quality disturbances from the grid sometimes cause distributed generators to trip offline, adversely affecting the economics of distributed generation projects.

\subsection{Other Technical Interconnection Issues}

\subsubsection{Utilities}

Twenty percent of utility interviewees noted that distributed generators frequently are required to disconnect from the grid because of nuisance trips and that these trips can adversely affect the distributed generation customer. Several utilities also highlighted the need to better understand the effect of multiple distributed energy systems on the grid and on networked feeders in particular.

\subsubsection{Customers/Manufacturers}

Customers and manufacturers raised a variety of additional technical interconnection issues. Twenty-seven percent of interviewees noted that "nuisance trips" affected the economic performance of distributed generation projects. These nuisance trips were characterized as arising because either the grid cannot provide a high level of power quality or tight protection requirements force the distributed generator to trip off far more frequently than is realistically necessary to protect the grid and public safety. Another issue raised was the need to better understand the effect of distributed energy penetration on feeders. 


\subsection{Business/Regulatory}

\subsubsection{Utilities}

Utilities had few concerns regarding business or regulatory interconnection issues. The most common concern, raised by $30 \%$ of utility interviewees, was that distributed energy manufacturers, installers, and customers are not properly educated about what is required to interconnect distributed energy systems with the grid and that they are not fully aware of the difficulties faced by utilities in managing the effect of these systems on the performance of the grid. Although several utilities noted that distributed energy customers, installers, and manufacturers can quickly come up the learning curve regarding interconnection issues after a few installations, it was felt that interconnection is often treated as an afterthought by the customer, leading to avoidable problems at the time of interconnection.

\subsubsection{Customers/Manufacturers}

Business and regulatory interconnection issues, rather than technical interconnection issues, were most frequently cited by customer and manufacturer interviewees. One of these issues is utility employee education. Twenty-seven percent of customer and manufacturer interviewees commented that, based on their experiences, utility employees are generally not well versed in how to interconnect distributed generation. Their experience has been that the DER manufacturer, installer, or customer often must provide this education to ensure that the utility completes the interconnection satisfactorily.

DER customers and manufacturers continue to find the inconsistency of state and national interconnection standards a major regulatory barrier to interconnection. Several states have chosen to implement technical interconnection standards for distributed generation that vary from the major national interconnection standards (i.e., the UL and IEEE standards) to some degree. To interconnect in these states, manufacturers and customers must spend extra time and money certifying their equipment to these additional requirements. This practice seems to negate much of the positive effect of having national interconnection standards in the first place. Texas and New York were singled out as states that have implemented interconnection standards with requirements inconsistent with national standards.

There is also variability in how utilities interpret interconnection standards. Several interviewees noted that state standards often leave too much open for interpretation by individual utilities, and utilities sometimes use this leeway to require more familiar but more expensive equipment when inexpensive equipment will perform equally well. This lack of consistency makes interconnection more difficult and expensive because customers and manufacturers cannot standardize their approach to interconnection even within a single jurisdiction.

Fees were also cited as a major barrier to interconnection because they can affect the profitable operation of a DER installation. These fees-in the form of competitive transition charges, standby charges, exit fees, interconnect fees, demand charges, and other fees - can severely affect project economics for distributed energy projects. Interviewees reported that their projects were hurt by these fees and that they did not understand how utilities or regulators could justify these charges and fees from an economic or technical perspective. 
Generally, the perspective of the interviewees was that utilities or regulators instead use these fees as a disincentive to the installation of distributed energy. Additionally, some interviewees noted that these charges seemed unfairly targeted toward DER because the same fees were not placed on other loads and generators on the grid that operate similarly to distributed energy.

Other concerns raised included a general lack of responsiveness by utilities toward approving interconnection requests. 


\section{Conclusions}

Sentech's analysis of the information collected for this study indicates that, although much progress has been made in recent years to facilitate the interconnection process, reduce technical barriers, and address policy and procedural approaches, significant perception gaps remain among the key players.

All the utilities interviewed have established interconnection procedures, and some utilities and electricity suppliers are embracing the concept of distributed generation. The primary technical issue for utilities is safety. Many are reluctant to support interconnection if they perceive any increased liability because of decreased safety for the customer or the utility worker. This increased liability threshold may be an unreachable goal for any DER to meet. The DER community, for its part, tends to view utilities' reluctance to interconnect as an anticompetitive attitude toward new market players.

Regulatory agencies such as state public utility commissions and the Federal Energy Regulatory Commission as well as organizations such as the IEEE and UL have recognized the need for standardization and regulation in this area and have begun to propose solutions. Interconnection standards promulgated by these groups, such as the IEEE 1547 standard and California's Rule 21, provide a valuable framework for interconnection. However, these standards still allow utilities some flexibility in setting requirements, which makes negotiation between the utility and the customer a necessary component of most interconnections in the United States today. As a result, the level of difficulty associated with a particular interconnection often depends on the knowledge level of individual utilities and customersespecially regarding the effect of the DER on the performance of the grid - and the attitude of the individual utility toward interconnected DER.

Sentech's interviews and assessments have revealed several common issues regarding interconnection. They are listed below.

\subsection{The Primary Concern of Utilities Is Safety and System Protection}

Fifty percent of the utilities interviewed cited the potential for distributed energy installations to island and cause safety or system reliability issues as their primary concern. Some utilities have the opinion that utilities have an obligation to serve their customers and that distributed energy could theoretically compromise their ability to meet that obligation by islanding or otherwise affecting the ability of the system to perform adequately.

Although islanding was the primary concern of utilities, most interviewees could not provide specific examples of DER compromising safety or system protection. Only $10 \%$ (one) of the utilities reported an actual incident in which distributed energy islanding compromised a lineman's safety. ${ }^{2}$ Although the small size of our survey sample negates any statistical significance of this ratio, the fact that most of the utilities interviewed noted islanding as their major technical issue indicates this is a concern that still needs to be resolved.

\footnotetext{
${ }^{2}$ Note that this distributed generation interconnection was illegal and made without the knowledge of the utility.
} 
Although several of the utilities interviewed stated that they are not inherently opposed to the concept of distributed energy, they are typically not willing to install distributed energy systems on their grids because they believe the systems will compromise the integrity of the grid or their ability to serve customers.

\subsection{DER Manufacturers and Customers Often View Interconnection Requirements as Unjustified and Anti-Competitive, but They Have Difficulty Proving These Claims}

Most customer interviewees identified unjustified interconnection requirements as their greatest technical interconnection issue. Eighteen percent of customer-side interviewees noted that utilities sometimes impose protective requirements that are designed to prevent a situation that is extremely unlikely to occur under real-world operating conditions. The concern that DER protective requirements are predicated on situations that can only be replicated in a laboratory was a frequent topic among customer-side interviewees.

Given the stringency of some interconnection requirements, there is a perception that utilities use technical interconnection requirements as a means of preventing the installation of distributed energy technologies on their grids. This perception appears to arise, in large part, from the perceived disconnect between the stringency of required protections and the likelihood that the situations the protections are designed to prevent will actually occur. Customer-side interviewees have difficulty, however, proving that interconnection requirements are unwarranted. Some interviewees felt that real-world validation of technical interconnection requirements would demonstrate the extreme nature of current requirements and would lead to standards that are more achievable for DER. Utilities generally believed that their interconnection standards are justified to protect the grid and that they must maintain flexibility in imposing interconnection requirements to handle the peculiarities associated with each DER interconnection application.

\subsection{IEEE 1547 Is a Key Piece to the Puzzle, but There Is Increasing Demand for More Detailed Interconnection Procedures That Can Help Standardize Interconnection Requirements Nationwide}

This need will be answered, in part, by a revision to IEEE 1547 based on supporting research and testing and the planned additional standards and guides to IEEE 1547. These additional documents, currently in draft form, include:

- $\quad$ P1547.1, Draft Standard for Conformance Test Procedures for Equipment Interconnecting Distributed Resources With Electric Power Systems

- P1547.2, Draft Application Guide for IEEE P1547 Draft Standard for Interconnecting Distributed Resources With Electric Power Systems

- $\quad$ P1547.3, Draft Guide for Monitoring, Information Exchange, and Control of DR Interconnected With EPSs. 
The passage of the IEEE 1547 standard has been heralded as an essential breakthrough in the drive toward a uniform national interconnection standard. Much work has been put into the effort to pass the IEEE 1547 standard for distributed generation interconnection, and IEEE 1547 fills an important gap by providing a national interconnection standard where none has existed before. Utilities and the DER community view the standard as an important step of improving the interconnection process.

However, many of the interviewees felt that imposition of the IEEE 1547 standard would do little to alter the state of interconnection in the short term because its specificity was reduced to gain passage. Therefore, there appears to be some urgency regarding the development of the supporting standards and guides.

It should be noted that some utilities mentioned that they would eventually integrate IEEE 1547 into their own interconnection requirements, but they viewed the IEEE standard as a minimum or baseline that could be altered as necessary. The tendency of utilities to modify the IEEE 1547 standard to meet their own needs is an issue that will need to be addressed because it may make it more difficult to develop a true national interconnection standard.

Distributed energy equipment manufacturers and system integrators are generally supportive of a national interconnection standard but appear to have concerns that the IEEE standard lacks the specificity necessary to allow them to design equipment to meet a single interconnection requirement. They are also concerned that these national interconnection standards sometimes contain protection requirements that are difficult and costly to meet because they are designed for laboratory situations rather than real-world situations.

Although there are reservations regarding IEEE 1547, most interviewees recognized it as an important first step of developing a national interconnection standard that meets the safety requirements of utilities while allowing distributed energy manufacturers to design for a single standard.

\subsection{Education About Interconnection and DER Issues Is a Common Goal of Utilities and Distributed Generation Customers/Manufacturers, but There Is a Difference of Opinion About Where Education Efforts Should Be Focused}

Among all parties, there appears to be a common belief in the value of education to increase knowledge of distributed energy interconnection issues. Thirty percent of utility interviewees and $27 \%$ of customer-side interviewees specifically mentioned education about interconnection issues as an area of concern. The focus of that education effort, however, is up for debate.

Utilities believe that their customers and DER manufacturers must become better versed in the difficulties that utilities face in the management of DER on their grids. Utilities feel that DER manufacturers and system integrators seldom take the needs of the utility or the system into account in the design of their installations. Utilities argue that integrating the needs of the utility and the interconnection process into a DER site plan from the beginning would substantially reduce the potential for a difficult situation to arise later in the process, when interconnection actually takes place. 
Distributed energy manufacturers, system integrators, and customers profess a general opinion that many utility system protection engineers do not have an adequate knowledge of how distributed energy will affect their system. It was felt that in the absence of this knowledge, these protection engineers require distributed energy installations to install overly stringent protections that are extremely costly. It was felt that an educational effort that would instruct protection engineers on distributed energy technologies would help ease the requirements placed on distributed energy and reduce interconnection costs for the DER community.

\subsection{Dialogue Is a Useful Tool in the Design of Interconnection Standards}

Recent years have seen the development of multiple interconnection standards using an inclusive process that involves all interested parties. Interviewees from both sides of the meter stated that they were most comfortable with an inclusive process as the best possible method for developing interconnection standards. The inclusive approach was generally felt to be the best approach to ensure that all stakeholders accept the new standard and feel that the final standard or regulation reflects their point of view. Such a method has its weaknesses (primarily that the necessity for compromise might weaken the overall standard from everyone's perspective). However, it is a vast improvement over a "regulation by edict" approach, which creates uncertainty as to the origin of regulations and fails to create a sense of buy-in or ownership among the affected parties. 


\section{Appendix A: Interviews}

\section{A.1 Methodology}

At the beginning of this project, a list of potential interview candidates was compiled based on input from a utility industry association and the project team. Additional interviews were arranged and conducted through unsolicited e-mails and telephone calls to prospective interviewees.

Between August and November 2002, Sentech conducted 35 interviews with companies in 14 states. Interviews were conducted by phone or in person using a basic series of questions (detailed in Appendix D) to guide the interview. In general, interviewees focused on their general interconnection experience with multiple distributed generation projects rather than on one specific interconnection example. There were some interviews, however, that focused on a particular distributed energy interconnection project. Although technical interconnection issues were the primary focus of the interviews, business and regulatory barriers to the interconnection of distributed energy were also discussed.

Following each interview, a case study was written based on the information obtained. This case study was e-mailed to the interviewee(s) to obtain revisions and corrections. In situations in which Sentech was unable to gain approval of the case write-up from the interviewee, that write-up was not included in the final report. Interviews not included as case write-ups in the final report are detailed in Appendix C.

Readers should note that the opinions expressed in the case studies in this report do not necessarily reflect the opinions of a particular company or organization. Rather, they express the opinions of knowledgeable individuals from within the utility and distributed energy industries and distributed energy consumers. In addition, please note that the interconnection requirements shown for each utility reflect the best information available at the time the interview took place. They should not be taken to explicitly represent the actual interconnection standards of that utility. Any party interested in interconnecting with the grid should contact the utility for the most up-to-date interconnection requirements prior to proceeding with interconnection.

It should be noted that this study was not intended to present a statistically significant result. As such, there was no attempt to take a statistically significant sample or perform statistical analysis based on the information collected. Instead, this study details and categorizes the major issues discussed during interviews and offers some commonalities and differences between the interconnection concerns of utilities and those of the DER community.

\section{A.2 Description of Issue Types}

This study uses the classifications for interconnection issues developed in the Making Connections report. These classifications (technical, business, and regulatory) are arbitrary designations with no finite boundary, but for the purposes of this report, they help categorize the issues raised and make it easier to focus on similar and related issues raised by interviewees. 


\section{A.2.1 Technical Issues}

Technical interconnection barriers include utility requirements intended to address engineering compatibility with the grid and grid operation. These barriers include specifications related to power quality, dispatch, safety, reliability, metering, local distribution system operation, system protection, and control. Examples include engineering reviews, design criteria, engineering and feasibility studies, operating limits, and technical inspections required by distribution utilities.

\section{A.2.2 Business/Regulatory Issues}

Business practice barriers relate to the contractual and procedural requirements for interconnection. Examples include contract length and complexity, contract terms and conditions, application fees, insurance and indemnification requirements, the necessity for attorney involvement, identification of an authorized utility contact, consistency of requirements, operational requirements, and delays.

Regulatory barriers include matters of policy that fall within the jurisdiction of state utility regulatory commissions or the Federal Energy Regulatory Commission. These are issues that arise from or are governed by statutes approved by the regulatory authority. Regulatory prohibition of interconnection, unreasonable backup and standby tariffs, local distribution system access pricing, transmission and distribution tariff constraints, independent system operator requirements, exit fees, anti-bypass rate discounting, and environmental permitting fall into this category.

\section{A.3 Interview Summaries}

In this section, Sentech has included 21 interview summaries.

Some interviews are omitted from the final report for one of the following reasons:

- The interviewee completed the interview but refused to have the results published.

- The interview did not yield enough information to warrant inclusion in the final report.

- The interview was conducted for background purposes.

A list of individuals and companies interviewed but not included in the final report is in Appendix C.

The interviews summarized in this section capture the essence of the technical aspects of the distributed energy interconnection experience as described in all the interviews.

The interviews are organized into two sections. One section contains interview summaries for utilities, and one section contains interview summaries for distributed generation manufacturers, customers, and other parties who operate on the customer side of the meter. 


\title{
A.3.1 Utility Interviews
}

\author{
Alliant Energy \\ Utility \\ Cedar Rapids, Iowa \\ www.alliantenergy.com \\ Russell Miller, system protection supervisor: russellmiller@alliantenergy.com
}

\section{Background}

Alliant Energy is an investor-owned utility that provides electric service to parts of Iowa, Wisconsin, Minnesota, and Illinois. Details in this write-up refer principally to Alliant's Iowa subsidiary.

\section{Distributed Generation Installed in Territory}

Most of the distributed generation on Alliant's system is located at commercial facilities and used for interruptible power and standby power. Alliant estimates that it has approximately $150 \mathrm{MW}$ of backup and interruptible power installed in Iowa. This is mostly diesel with some natural gas-fired units. In addition, $100 \mathrm{MW}$ of diesel units are installed in small towns and run at peak demand times. Approximately $80 \%$ of these distributed generation installations are in the range of 1-3 MW, and a few are in the range of 10-15 MW. The average unit runs fewer than 80 hours per year.

Alliant also has several single wind turbines operating in its service area. These are typically $250 \mathrm{~kW}$ and were installed in Iowa under a state-mandated payment plan of $\$ 0.06 / \mathrm{kWh}$ for alternative energy. This payment plan has ended, and now most wind turbine installations are in larger, commercially run wind farms. In Alliant's Iowa service area, $280 \mathrm{MW}$ of wind turbines are installed in commercial wind farms.

Distributed generation installations that run primarily off methane at landfills and farms are also popular (although figures of megawatts installed were unavailable). These typically involve internal combustion engines, but one Capstone microturbine has been installed as well. In addition to this Capstone installation, Alliant has five other Capstones on its system. One is at a nursing home, and four are at a substation to reduce peak load on a transformer.

At factories, approximately $90 \%$ of diesel sets are on $480-\mathrm{V}$ or $4.16-\mathrm{kV}$ plant internal power busses. Some other sets are tied into a $12.5-\mathrm{kV}$ bus. The size of units is typically $750-2,000$ $\mathrm{kW}$, and usually there are two or more units.

Approximately $90 \%$ of wind sets, typically the large commercial wind installations, generate at $590 \mathrm{VAC}$ and tie into the high-voltage transmission or distribution system through a stepup transformer. Small wind units typically generate DC current and use an inverter at 120 or $240 \mathrm{VAC}$, single phase. Microturbines are generally $30 \mathrm{~kW}$ and run at 480 or 120/208. 
There are three PV systems in Alliant's Iowa territory, all metered separately. Net metering is performed by reading both meters on an installation and netting out the total due to the customer or the utility. PV systems are generally $1-3 \mathrm{~kW}$ and use inverters to tie directly into the residence's distribution system.

\section{Interconnection Requirements}

Alliant has developed its own guidelines for distributed generation based on the experiences of other companies. Alliant anticipates that it will adopt IEEE 1547 standards, potentially with some modifications to suit the needs of the utility. It is not yet clear what those modifications will be.

\section{Interconnection Costs}

Although the cost of interconnection equipment varies by installation, a typical material cost for utility protection relays in a $1-5 \mathrm{MW}$ plant is $\$ 5,000$ (based on a modern digital multifunction relay such as an SEL 351). Installation costs can vary substantially depending on the equipment installer used by the customer.

Alliant requires all customers with distributed generation less than $200 \mathrm{~kW}$ to pay a $\$ 275$ fee to cover the cost of an engineering study. For smaller units, this study concentrates on fault ratings. Some larger units may be required to pay only a $\$ 275$ fee if initial screenings show no problems. If the initial screening shows that further modeling is required, Alliant provides a cost estimate to the consumer and requests approval before incurring additional costs. A study for a larger unit will include load flow and fault studies and potentially a stability study. Smaller distributed generation interconnections are typically expedited because they require only information exchange rather than a complete study. Larger units can take longer and involve more complex studies.

\section{Major Technical Requirements}

Alliant requires a visible disconnect for all units. The type or make of disconnect switch is not specified, provided that it meets ratings and is visible and lockable. Transfer trips may be installed in some cases if the relays cannot provide anti-islanding protection. In this case, the utility supplies and installs the transfer trip at customer expense.

\section{Power Electronics}

Alliant currently requires utility-grade relay systems on units larger than $200 \mathrm{~kW}$, though this may change as Alliant incorporates the IEEE 1547 standard into its own protocols. Alliant allows most types of utility-grade relay systems, which must provide over/under voltage, over/under frequency, and reverse power when possible.

For units smaller than $200 \mathrm{~kW}$, Alliant allows industrial-grade relays. Basler and Wilmar relays are preferred, but Alliant would accept other equipment if performance information was provided. For small wind power and solar PV systems with inverters, Alliant does not require additional protection provided that they meet UL ratings and are certified non-islanding. 
Alliant generally observes larger utility-grade systems to ensure that they are non-islanding and that they are operating properly. This observation ensures that the system operates as designed and includes a simulation of loss of grid to observe tripping away from the grid as well as a review of the utility tie relay.

\section{Voltage Requirements}

Relays should be capable of providing a trip time in the range of $1 / 2-2$ seconds. Actual voltage and time delay settings are determined on a case-by-case basis.

\section{Frequency Requirements}

Alliant requires that the relay be capable of providing a trip time in the range of $1 / 2-2$ seconds. Actual frequency and time delay settings are determined on a case-by-case basis.

\section{Power Factor}

The customer is required to maintain a power factor, measured at the point of interconnection, of unity $( \pm 10 \%$ for generators with a capacity less than $200 \mathrm{kVA}$ and $\pm 5 \%$ for all other installations).

\section{Harmonics}

Alliant does not specify filters but does limit harmonics and voltage distortion (using IEEE 519 standards) that may result in filters being added.

\section{Specific Technical Interconnection Issues}

\section{Nuisance Trips}

Customers operating parallel to the grid have to deal with the fact that breakers will frequently disconnect them from the grid because of blips in the system. These "blips" vary by technology type. For example, trips on wind units usually occur in 15 cycles for voltage dips of $10 \%$ and in 6 cycles for dips of $15 \%$. At times, such as during storms, when a fault is experienced on a feeder that is not on the same line as the distributed generation asset, the distributed generation will isolate from the grid on voltage relays (typically set at $+/-10 \%$ for $1 / 2-1$ second) and overload if it is too small (only if it is providing a local load). This can be prevented by isolating the distributed generation during a storm to prevent the first blip or resetting time delays to reduce nuisance trips.

\section{Specific Business/Regulatory Interconnection Issues}

None was noted. 


\section{Anonymous Midwestern Utility}

\section{Background}

This is a large Midwestern utility.

\section{Distributed Generation Installed in Territory}

The utility's experience with distributed generation has been mainly with customer-side installations, but it is conducting some pilot projects in the area of utility-owned distributed generation. It has approximately 100 distributed generation installations operating on its grid.

The utility generally receives $35-50$ applications for interconnection each year. The typical installation size of an application is between $200 \mathrm{~kW}$ and $3 \mathrm{MW}$. Most installations are dieselor natural gas-fired units for emergency and backup applications, though there have been a few PV and microturbine installations. Only a few of the distributed generation installations in the service territory export power to the grid.

\section{Interconnection Requirements}

\section{Interconnection Costs}

The utility operates in a state that employs interconnection standards. Customers installing distributed generation pay a standard $\$ 250$ fee to apply for interconnection. This fee covers the utility's standard costs to process an interconnection application.

\section{Technical Interconnection Requirements}

Requirements listed are for single-phase installations less than or equal to $25 \mathrm{~kW}$ or threephase installations less than or equal to $300 \mathrm{~kW}$. For units less than $300 \mathrm{~kW}$, no study is required as long as the interconnection and generation equipment are on a pre-approved list and the installed generation size is not more than $15 \%$ of peak load at that location. If the interconnection application meets these criteria, no further study is required. If a distributed generation unit's penetration reaches more than $15 \%$ of peak load between switching points, an integration study is required.

For units more than $300 \mathrm{~kW}$, interconnection becomes more difficult, and synchronization can be an issue. As a result, the utility places these larger distributed generation interconnections under greater scrutiny. Inspections are performed on all installations larger than $1 \mathrm{MW}$. The utility requires a disconnect switch to isolate the distributed generation equipment for safety purposes.

Any installation that will export power to the grid must also undergo a study paid for by the consumer to determine whether system upgrades are required of the utility or the customer to accommodate the interconnection. 


\section{Power Electronics}

The equipment used to interconnect must either be certified by the utility based on past operating experience within the utility territory or undergo performance testing by the manufacturer or an independent testing lab for the following requirements:

- Over/under voltage trip

- Over/under frequency trip

- Synchronization

- Harmonic limits

- DC current injection limits

- Anti-islanding

- Prevention of connection or reconnection to de-energized system.

No further study is required if the interconnection and generation equipment are on a preapproved list and the installed generation size is not more than $15 \%$ of peak load at that location.

\section{Voltage Requirements}

- Less than $50 \%$ voltage: 10 cycles

- $50 \%$ to less than $88 \%$ voltage: 120 cycles

- $110 \%$ to less than $120 \%$ voltage: 60 cycles

- More than or equal to $120 \%$ of normal voltage: 6 cycles

Frequency Requirements

All distributed generators must operate at frequencies between $59.3 \mathrm{~Hz}$ and $60.5 \mathrm{~Hz}$. Outside of this range, distributed generation less than or equal to $10 \mathrm{~kW}$ must disconnect within 10 cycles. Distributed generation larger than $10 \mathrm{~kW}$ must disconnect within 10 cycles when frequency exceeds $60.5 \mathrm{~Hz}$ and be capable of time-delayed disconnection for frequencies between $59.3 \mathrm{~Hz}$ and $57 \mathrm{~Hz}$.

Power Factor

Power factor not listed

\section{Harmonics}

As required under IEEE 519 


\section{Specific Technical Interconnection Issues}

Safety of Distributed Generation on the System

The utility had not experienced specific technical problems with distributed generation installations interconnected with the grid. However, it expressed concern about islanding and safety issues during interconnection. It noted that protection to the system is critical, and, as such, protection settings on an operating distributed generation system are closely monitored. Although the utility has not encountered any specific performance or safety issues with its distributed generation interconnections to date, its concerns include load flows, re-energizing faulted lines during restoration work, relay miscoordination, and resynchronizing an islanded customer to the grid.

\section{Specific Business/Regulatory Interconnection Issues}

None was noted. 
Central Hudson Gas \& Electric

Utility

Poughkeepsie, New York

www.cenhud.com

Tom Duffy: tduffy@cenhud.com

\section{Background}

Central Hudson Gas \& Electric provides gas and electric service to the Mid-Hudson River Valley in New York.

\section{Distributed Generation on System}

Distributed generation installations are generally not economical within Central Hudson's territory because distributed generation cannot compete on a cost basis with Central Hudson's low price per kilowatt-hour $(\$ 0.08 / \mathrm{kWh}$ for residential customers). Some distributed generation has been installed for backup or standby purposes.

The only recent installations of distributed generation in Central Hudson's territory are small $\mathrm{PV}$ installations for residential applications, typically $2 \mathrm{~kW}$ or less. Approximately 12 have been installed, each through a single meter. Installations of PV are primarily driven by Central Hudson's net metering tariff, which applies to PV systems less than $10 \mathrm{~kW}$ and can make PV financially viable in the area. New York's net metering tariff allows customers to offset usage at full retail price.

\section{Interconnection Experience}

When distributed generation interconnections do occur, Central Hudson follows New York State's standard interconnection requirements (SIR) and net metering requirements, which require type testing for interconnection technologies. The SIR applies to systems of 300 kVA or less.

It was noted that some distributed generation proponents still believe that the lack of a streamlined interconnection process hampers the growth of distributed generation. However, the interviewee noted that New York has already instituted a standardized process for distributed generation installations rated $300 \mathrm{~kW}$ and less on radial feeders. Despite this, the initial and operational costs of distributed generation make it difficult to compete with retail delivery service unless additional benefits such as power quality or green power concepts are factored in.

\section{Interconnection Costs}

Under the New York SIR, each applicant for interconnection must pay a standard \$350 application fee. There is no application fee for interconnections of $15 \mathrm{kVA}$ or less. 


\section{Technical Interconnection Requirements}

\section{Power Electronics}

New York allows type testing by independent third-party laboratories for specific protection packages. Once a protection package passes the type test, it is eligible for use with all utilities in New York State. Changes to hardware or software may require additional type testing.

\section{Voltage Requirements}

For systems of $300 \mathrm{kVA}$ or less (nominal $120 \mathrm{~V}$ RMS base):

- Less than $60 \mathrm{~V}: 6$ cycles

- More than $60 \mathrm{~V}$ to less than $106 \mathrm{~V}: 2$ seconds

- More than $132 \mathrm{~V}$ to $165 \mathrm{~V}: 2$ seconds

- More than $165 \mathrm{~V}: 2$ cycles

Frequency Requirements

For systems $300 \mathrm{kVA}$ or less (nominal $120 \mathrm{~V}$ RMS base):

- $\quad 59.3 \mathrm{~Hz}$ to $60.5 \mathrm{~Hz}$ : 6 cycles

\section{Power Factor}

For systems $300 \mathrm{kVA}$ or less:

- 0.9 leading or lagging

\section{Harmonics}

For systems $300 \mathrm{kVA}$ or less:

- In accordance with IEEE 519

\section{Specific Technical Interconnection Issues}

\section{Pre-Certification}

It was noted that pre-certification by third parties can be valuable in facilitating the installation of distributed generation on the grid because it eliminates the need for individual testing of each system. However, pre-certification can also be risky if pre-certified equipment loses that certification. For example, customers of utilities throughout the nation, including Central Hudson, were adversely affected by an incident in which an inverter that was previously certified by an independent testing laboratory lost its certification after customers had already installed it. The inverter could not meet the harmonics requirements and antiislanding requirements necessary for pre-certification. Because the inverter was no longer precertified, Central Hudson felt compelled to remove these inverters from its grid until the inverter manufacturer could provide a solution to the problem. This adversely affected customers who had chosen to use this inverter and prevented them from using their DER in an interconnected mode until the problem was resolved. 


\section{Specific Business/Regulatory Issues}

IEEE P1547

The interviewee noted that IEEE's proposed P1547 standard might initially limit the ability to streamline the interconnection process because it describes functional rather than prescriptive requirements that remain subject to study and interpretation. However, it provides a valuable baseline for revisions and the development of companion documents (e.g., for application, testing, and monitoring). The interviewee believed that IEEE P1547 does not provide enough information to customers regarding the necessity of studies to understand the interaction between the generator and the grid. (Note: Since the time of these comments, IEEE P1547 has been approved by IEEE and published as a new standard, IEEE 1547).

\section{Standard Market Design}

The interviewee noted that the establishment of a standard market design, in which distributed generators contribute toward the true cost of service of using delivery systems, will contribute to the development of a market for distributed generation by allowing delivery companies to recoup their costs without cross-subsidizations. This will allow distributed generation to compete fairly on the system. 


\section{Conectiv}

Utility

Newark, Delaware

www.conectiv.com

Steve Steffel: steve.steffel@conectiv.com

\section{Background}

Conectiv is a utility that provides service to Delaware and parts of New Jersey, Maryland, and Virginia.

\section{Distributed Generation Installed in Territory}

Conectiv has deployed diesel engines for reliability and grid support while upgrades to the transmission and distribution systems are under way. It has also operated backup units at customer facilities. Typical installations are 1.25-1.5 MW for diesel generators. Conectiv is also participating in a pilot project to test microturbines and mobile gas engines, has two customer-proposed wind farms of 5-8 turbines and 7-8 MW, and has some small PV systems (less than $25 \mathrm{~kW}$ ) that have been installed by customers in its territory.

For residential installations, homeowners usually connect to the grid at 120/240 V. Depending on the net metering regulations in their particular state, residential customers usually connect through a single meter for installations up to $25 \mathrm{~kW}$ (in Maryland or Delaware) or $100 \mathrm{~kW}$ (in New Jersey). For larger gensets, relaying and breakers are required. For Conectiv's own distributed generation installations, it has used mobile distributed generation trailers, threephase pad mount transformers to step up voltage, and reclosers with Schweitzer relays for protection to interface the units with the grid. These larger units generally connect at $480 \mathrm{~V}$ to a transformer that converts to $12,470 \mathrm{~V}$.

\section{Interconnection Requirements}

Conectiv employs two standards for interconnection: one for systems larger than $1 \mathrm{MW}$ and one for systems less than $1 \mathrm{MW}$. It has an accelerated approval procedure for customerinstalled microgeneration.

Net metering is allowed in Conectiv's territory for installations less than $25 \mathrm{~kW}$ (in Maryland and Delaware) or $100 \mathrm{~kW}$ (in New Jersey). Net metering installations normally receive approval under the accelerated process.

\section{Interconnection Costs}

Generators less than $25 \mathrm{~kW}$ are exempt from a pre-interconnection study. For other generators less than $1 \mathrm{MW}$, Conectiv will pay the cost of an interconnection study up to the typical and customary cost for such a study; costs above this are the responsibility of the customer.

For larger installations, the customer is required to pay for an engineering study and any upgrades needed to the electrical grid. Study cost varies by the location and size of the generator. These studies originate with Federal Energy Regulatory Commission and are administered by the utility. 
Conectiv requires the customer to pay for upgrades necessary to connect the generator to the system. At the transmission level, the customer can get credit if the generation installation defers a transmission upgrade. However, this credit can only be up to the connection cost and cannot create a profit for the generator. Upgrades may involve distribution line capacity if the flow back from a distributed generation site requires a bigger conductor for certain sections of a distribution circuit. Substation equipment capacity may also need to be upgraded.

In one case, Conectiv had a location where existing generation was already using most of the capacity of a $69 / 12-\mathrm{kV}$ transformer. This required either that the new generator curtail when both generators were running during low-load periods or that the transformer be upgraded to ensure the ability to run at full output.

Protective requirements such as transfer trip may also need to be upgraded if the ability to quickly reclose on the feeder is necessary (as in areas in which the presence of other commercial or industrial customers necessitates a quick reclose to protect the processes and control electronics used by them). Conectiv does not specify the communication or transfer trip equipment, but the cost of such equipment can range from $\$ 20,000$ to $\$ 50,000$. The customer who installs the distributed generation must pay for any issues identified in the engineering study.

\section{Technical Interconnection Requirements (for Systems Less Than 1 MW)}

\section{Power Electronics}

For microgeneration, Conectiv reviews the design of the power electronics and may precertify the design. Pre-certification is based on meeting all applicable industry requirements, adhering to Conectiv's guidelines, and passing a review by Conectiv's System Protection Group. Conectiv allows accelerated approval for customers installing systems with a precertified power electronics package. As long as the power electronics setup is not modified and the size is within the net metering tariff, the utility will approve the interconnection based on notification from the customer.

\section{Voltage Requirements}

Voltage trip requirements for inverters up to $25 \mathrm{~kW}$ :

- Less than 50\% voltage: 0.1 second

- $50 \%$ to less than $88 \%$ voltage: 2 seconds

- More than $106 \%$ to less than $137 \%$ voltage: 2 seconds

- $137 \%$ voltage or more: 0.03 seconds 
Voltage trip requirements for inverters larger than $25 \mathrm{kV}$ (specific set points and time delay determined for each installation):

- Less than $50 \%$ voltage: 0.1 second

- $50 \%$ to less than $88 \%$ voltage: 0.1 to 30 seconds

- More than $106 \%$ to less than $137 \%$ voltage: 0.1 to 30 seconds

- $137 \%$ voltage or more: 0.03 seconds

Voltage trip requirements for non-inverter or rotational machines (specific set points and time delay determined for each installation):

- Less than $90 \%$ or more than $110 \%$ : 0.1 seconds to 30 seconds

- $115 \%$ or more: 0.1 seconds

Frequency Requirements

$59.3 \mathrm{~Hz}$ to $60.5 \mathrm{~Hz}$ : 0.1 seconds

Power Factor

0.85 lagging or leading (when output exceeds $10 \%$ of inverter rating for inverter-based systems)

\section{Harmonics}

Must meet requirements of IEEE 519

\section{Specific Technical Interconnection Experience}

Trips During Momentary Interruptions

Conectiv's overall experience with distributed generation interconnection has been positive. In a few cases, it has had problems when distributed generation trips during momentary interruptions of the feeder or the sub-transmission system. This typically happens when a line trips to clear a temporary fault and causes the distributed generation unit to trip to prevent overspeed. When the line comes back on, the load is high and lacks generation support, which causes voltage to sag and prevents the distributed generation from closing back in. Although this problem is rare, it has occurred with combustion turbines.

In addition, Conectiv has seen distributed generation trip when a supply line to an area had a switching operation (of up to 30 seconds) and voltages sagged below $87 \%-90 \%$ for 10 seconds. In response, the utility has reconfigured automatic line equipment when installing grid-support distributed generation. This includes putting capacitors on voltage control, installing transfer trip, or putting feeder breakers on single reclose. Although these protections cannot completely prevent such problems, they can create redundancies in the system and prevent cascading outages. 


\section{Available Short Circuit}

In some areas, Conectiv is beginning to experience available short circuit that is too high on the distribution circuits for customer switchgear. As a result, all new distributed generation in the affected area is likely to be interconnected directly with the transmission system if it plans to operate in parallel. If the customer plans to operate only in isolated mode, the generator is still allowed to connect with the distribution grid. Any distributed generation interconnection with the transmission system is done through a substation. For example, if the substation takes $69 \mathrm{kV}$ as its source, the distributed generation is stepped up to $69 \mathrm{kV}$. Relaying requirements are set to provide proper protection against islanding or closing in out of phase.

In one case, in an area where short circuit values are a problem on the sub-transmission level (which is considered distribution level by Conectiv), a customer wishing to operate in parallel was required to connect to the transmission system. Operating in isolation would not have required a connection to the transmission grid.

\section{Specific Business/Regulatory Interconnection Issues}

None was noted. 
Idaho Power
Utility
Boise, Idaho
www.idahopower.com
Kip Sikes: ksikes@idahopower.com

\section{Background}

Idaho Power is an investor-owned utility that provides electric service to southern Idaho and eastern Oregon. Although the majority of Idaho Power's electricity is generated from hydroelectric facilities, its parent company, IDACORP, has made major investments in the distributed generation field, including a stake in fuel cell developer IdaTech. IDACORP also used to own Applied Power Corp. Idaho Power has strategically located distributed generation on the system to provide backup capacity for reliability and supply constraints.

\section{Distributed Generation Installed in Territory}

Last year, Idaho Power received more than 70 applications for interconnection. In addition, more than 75 projects are currently interconnected with Idaho Power's system.

\section{Interconnection Experience}

Idaho Power has established technical interconnection requirements for all distributed generators that wish to interconnect with the grid. This has allowed it to develop interconnection experience and to adapt its policies to deal with the differing needs of each interconnection. Specific adaptations to its interconnection policy have primarily related to protection settings and equipment such as transformer connections and design for fault contributions. To improve reliability to existing customers, Idaho Power has also reduced recloser delay settings as fault detection and clearing of distributed generators have improved, and it has altered the location of capacitor banks relative to reclosers and generators.

\section{Interconnection Costs}

Idaho Power runs all distributed generation interconnection applications, regardless of size, through the same evaluation process. The first stage is a feasibility study, which examines how the generator will affect the utility system and determines whether the system can absorb the additional generation capacity. Components of this study include determining the location relative to existing facilities and the need for facility extensions, voltage change or effect on existing customers, capability (including phases available) and condition of existing facilities, and approximate area load on facilities relative to the amount of existing generation plus proposed generation. Based on this feasibility study, additional system impact studies or facility studies may be ordered. Smaller projects can move through the process more quickly because they typically have less effect on the grid. 


\section{Technical Interconnection Requirements}

\section{Power Electronics}

Idaho Power does not require utility-grade breakers for interconnection of small projects but instead allows the generator to install his own breaker, provided it meets the requirements of the utility. If equipment is utility-grade, Idaho Power does not require performance testing. However, it does require "acceptance testing" prior to energization to verify that the protection equipment has the proper settings. This is because the incorrect setting of protection equipment is a fairly common problem for Idaho Power. Testing can be performed by the utility or by a qualified testing firm under guidelines laid out in the utility's interconnection procedures.

Rather than relying only on pre-certification, Idaho Power also requires periodic performance testing throughout the life of the interconnection. Performance testing is done independently and at the customer's expense. This testing ensures that, after installation, set points have not been changed, the protection still meets the utility's interconnection requirements, and the protection equipment still meets safety codes and standards.

Voltage Requirements

Less than $100 \mathrm{kVA}$ :

- Less than $60 \mathrm{~V}: 10$ cycles

- $60 \mathrm{~V}$ to less than $106 \mathrm{~V}: 2$ seconds

- More than $132 \mathrm{~V}$ to $144 \mathrm{~V}: 1$ second

- More than $144 \mathrm{~V}$ : 10 cycles

$100 \mathrm{kVA}$ or greater:

- Utility discretion

Frequency Requirements

Less than $100 \mathrm{kVA}$ :

- $\quad 59.3 \mathrm{~Hz}$ to $60.5 \mathrm{~Hz}: 10$ cycles

$100 \mathrm{kVA}$ or greater:

- Utility discretion

Power Factor

0.9 leading or lagging

\section{Harmonics}

As required under IEEE 519 


\section{Specific Technical Interconnection Issues}

\section{Safety of Linemen and the Grid}

Idaho Power had an incident in which a customer plugged generation into the grid without notification, and a company employee was electrocuted as a result. Consequently, for interconnection of small distributed generation, Idaho Power is most concerned about safety and correct operation to protect people and equipment.

\section{Voltage Regulation}

Some of the most important technical interconnection issues Idaho Power has encountered are voltage issues, though these depend on the equipment and specifications used by the customer. One problem developed with a synchronous generator with manual field excitation, which constantly changed reactive flow on the utility's system and caused device operation in response. Idaho Power corrected this problem by replacing the exciter and operating it at unity power factor to follow system voltage. This allowed utility control systems to regulate system voltage.

The utility has also required studies of some $100-\mathrm{kW}$ to $200-\mathrm{kW}$ systems that have voltage regulation issues because of their location on the grid. Study results indicated that the location of the generators relative to small conductor/high system impedance, and neighboring customers and customers further down the line, created voltage flicker during start and load rejection voltage issues on other branches of the same feeder. Although the generators could not move the system back at the substation, the local area with single-phase service was significantly affected. The mitigation costs were deemed too expensive by the developers and the projects were dropped.

\section{Voltage at System Start-Up}

Idaho Power has also experienced problems with voltage at start-up of distributed generation. In one installation, because of high system impedance and voltage rise to the generator at full output, transformer taps were set to buck voltage to the generator to allow its terminal voltage to be near or slightly under nominal. When the generator was off line and system voltage was in the lower part of the normal range under light load conditions, the voltage sensed at the protection package was too low to allow the breaker to close, which prevented the generator from synchronizing with the system. This was fixed by reducing the low voltage trip setting to allow the breaker to close.

\section{Ability to Maintain Voltage on the Grid}

At times, the installation of distributed generation affects system voltage and makes it difficult for the utility to maintain service to all customers on the grid. For example, high voltage at light load in the area of the generation can be caused by voltage rise from power injection from the distributed generator. In addition, low voltage on remote parts of the feeder or on adjacent feeders from the same substation at peak load conditions can be caused by an apparent load reduction (addition of generation). In response, the system voltage regulation reduces voltage for the conditions, which causes low voltage for customers not near the generator. Although not well understood by most generators, the transmission and distribution system was designed to serve load, not receive generation and serve load. 


\section{Islanding}

Other issues with distributed generation interconnection include islanding, which is not viewed by Idaho Power as a big concern if protective relaying is done properly. As a general policy, Idaho Power requests power factor control instead of voltage control to regulate antiislanding provisions. Maintenance of tight frequency and voltage settings is also stressed.

\section{Specific Business/Regulatory Interconnection Issues}

\section{Customer Education on the Interconnection Process}

Idaho Power is concerned that customers do not have a good understanding of the interconnection process and that they need to be better educated about interconnection. Dealing with project developers is also a concern because developers sometimes do not recognize that the utility approaches the interconnection process separately from the potential sale of electricity to the grid. Developers sometimes see interconnection and the sale of power as one issue and accuse the utility of not allowing interconnection when other issues, such as the inability to sell power at a profit, are actually preventing the project from going on-line. 
Los Angeles Department of Water and Power

Utility

Los Angeles, California

www.ladwp.com

Robert Castro: robert.castro@ladwp.com

\section{Background}

The Los Angeles Department of Water and Power (LADWP) serves as the municipal utility for the city of Los Angeles.

\section{Distributed Generation Installed on System}

This information is not available.

\section{Interconnection Experience}

As a municipal utility, LADWP is not required to participate in California's Rule 21, which governs the interconnection of distributed generation. LADWP has not adopted Rule 21 yet, but it is likely that the utility will adopt it eventually. LADWP has developed its own interconnection procedure, which was described as conservative and focused on safety, for operating in parallel with the grid. The procedure includes requirements for over/under voltage and over/under frequency, power factor, signal distortion, and generator disconnect.

In general, the incentive to install distributed generation on the customer side of the meter does not exist within LADWP territory because LADWP has low rates. LADWP charges around $\$ 0.10 / \mathrm{kWh}$ ( $\$ 0.08$ can be avoided). The utility finds that many customers apply for interconnection, but not many follow through with it. In addition, the city charter does not allow for third-party generation of any size, which hinders the growth of distributed generation by eliminating the possibility of selling to the grid by a third party.

\section{Interconnection Requirements}

\section{Interconnection Costs}

Customers must bear the cost of interconnection, including extensions or modifications to the electric system and related facilities.

\section{Major Technical Requirements}

\section{Power Electronics}

LADWP requires UL listing for all interconnection equipment.

\section{Voltage Requirements}

- Less than $92 \mathrm{~V}: 2$ seconds

- More than $138 \mathrm{~V}: 2$ seconds 
Frequency Requirements

- Less than $57 \mathrm{~Hz}: 2.5$ seconds

- More than $61 \mathrm{~Hz}: 2.5$ seconds

Power Factor

- Less than $1 \mathrm{MW}$ : average monthly on-peak power factor not less than $85 \%$ lagging

- $1 \mathrm{MW}$ or more: $99.5 \%$ lagging or $100.5 \%$ leading

\section{Harmonics}

Five percent of RMS value of service voltage and $25 \%$ of current waveform

\section{Specific Technical Interconnection Issues}

\section{Safety of Linemen and Customers}

LADWP's concerns with distributed generation interconnection revolve principally around safety for linemen and customers and protection of the grid, though it has not yet experienced any specific safety issues resulting from distributed generation. Anti-islanding is a major concern, as is the installation of reverse flow meters, appropriate signage to indicate the presence of distributed generation, utility access to the units, and the installation and verification of a visible disconnect in the form of a separate switch. LADWP has not yet had the opportunity to incorporate the appropriate provisions of the IEEE 1547 standard into its interconnection requirements.

\section{Effect of Baseload Penetration of Distributed Generation on the Grid}

The effect of significant base-load penetration of distributed generation on the transmission and distribution system has not been studied to the extent necessary.

\section{Specific Business/Regulatory Interconnection Issues}

\section{Capital Cost Recovery for Utilities}

This utility is concerned about capital cost recovery. Its position is that customers using distributed generation must be willing to pay for existing infrastructure installed to serve their load and provide backup when the customer's generation goes off-line or must go gridindependent and risk loss of power. 
Long Island Power Authority

Utility

Uniondale, New York

www.lipower.org

Andris Garsils: agarsils@keyspanenergy.com

\section{Background}

Long Island Power Authority (LIPA) is a municipal utility serving most of Long Island, New York.

\section{Distributed Generation Installed in Territory}

LIPA serves a densely populated, mostly urban and suburban area with few large commercial or industrial customers and a fully developed transmission and distribution grid. This removes several prime drivers for the installation of distributed generation. LIPA's customer base does not contain many customers that would derive substantial economic benefits from combined heat and power distributed resource installations. Most recent distributed generation installations in LIPA's territory have been packaged cogeneration systems of 60-120 kW (usually manufactured by Coast Intelligen). These interconnections have gone well. LIPA has also funded an aggressive rebate program to encourage customers to install PV systems up to $10 \mathrm{~kW}$.

LIPA has a wide variety of distributed generation installed on its system. Smaller (less than 2 MW) systems include:

- Seven commercial PV systems totaling $250 \mathrm{~kW}$

- One 1.4-MW landfill methane installation

- 350 smaller PV systems totaling 1.8 MW that have interconnected, have interconnection pending, or are applying for interconnection

- Three PV installations totaling 1.1 MW

- Four wind turbines totaling $80 \mathrm{~kW}$ (Three $30-\mathrm{kW}$ and one $50-\mathrm{kW}$ system)

- Ten customers running grid-independent with combustion turbine, running on natural gas or a blend of natural gas and sewage treatment gas, totaling $2.5 \mathrm{MW}$.

\section{Interconnection Experience}

LIPA has elected to follow the interconnection procedures established by the New York Public Service Commission (the New York SIR), which were developed following a collaborative process involving all interested parties. For interconnection of systems less than $300 \mathrm{kVA}$, LIPA follows the New York SIR and finds them to be adequate for its system protection and safety requirements. The New York standard is geared toward distributed energy technologies with internal interconnection control and protection schemes and allows distributed resource equipment that meets the type-testing criteria to operate in parallel with the radial electric distribution system without additional protective relaying.

LIPA maintains a single group within the company for all aspects of distributed generation interconnection and contract administration. This eases accountability and allows for a single interface with the customer. 
As installers or customers gain experience working with LIPA, it has found that the interconnection process generally becomes smoother. The majority of LIPA's interconnection experience is with traditional synchronous or induction generators. Installers of these technologies who have significant experience with interconnection have no noticeable issues interconnecting with the LIPA system today.

\section{Interconnection Requirements}

The general requirements of the New York standard are complementary with IEEE 1547 and UL 1741, but New York does have an additional requirement that all inverters meet a surge withstand capability test. This requirement is not presently part of UL 1741 but will be included in the next revision. In the interim, power electronics manufacturers must have their systems tested separately for this function to be listed as type-tested in New York.

\section{Interconnection Costs}

Under the New York SIR, each applicant for interconnection of systems up to $300 \mathrm{kVA}$ must pay a standard $\$ 350$ application fee. There is no fee for applications for interconnections of 15 kVA or less.

\section{Major Technical Requirements}

\section{Power Electronics}

If non-type-tested systems are installed for parallel operation, LIPA requires independent verification that relays are properly installed and functioning. Customers are required to hire an independent third-party tester, who tests the system for calibration and functional trip test and submits a relay test report to the utility. The installer or customer pays for this service, which is usually also required for insurance purposes.

For synchronous and induction generators up to $300 \mathrm{kVA}$ that are not type-tested, LIPA requires direct transfer trip (depending on the minimum load-to-generation ratio and location on the system) and potentially SCADA with supervisory trip. For induction generators less than $300 \mathrm{kVA}$, LIPA requires direct transfer trip and possibly SCADA, depending on the potential for islanding at the installation.

\section{Voltage Requirements}

For systems $300 \mathrm{kVA}$ or less (nominal $120 \mathrm{~V}$ RMS base):

- Less than $60 \mathrm{~V}: 6$ cycles

- More than $60 \mathrm{~V}$ to less than $106 \mathrm{~V}: 2$ seconds

- More than $132 \mathrm{~V}$ to $165 \mathrm{~V}: 2$ seconds

- More than $165 \mathrm{~V}: 2$ cycles 
For systems greater than $300 \mathrm{kVA}$ :

- Generating equipment must produce voltages within 5\% of nominal when operating in parallel and disconnect within one second if voltage is not within $10 \%$ of nominal

Frequency Requirements

For systems $300 \mathrm{kVA}$ or less (nominal $120 \mathrm{~V}$ RMS base):

- $\quad 59.3 \mathrm{~Hz}$ to $60.5 \mathrm{~Hz}$ : 6 cycles

For systems more than $300 \mathrm{kVA}$ :

- $60.5 \mathrm{~Hz}$ or more: 0.5 second

- $58 \mathrm{~Hz}$ or less: 1 second

Power Factor

- For systems $300 \mathrm{kVA}$ or less: 0.9 leading or lagging

- For systems more than $300 \mathrm{kVA}$ : between 0.9 and 1 leading or lagging

\section{Harmonics}

- For systems $300 \mathrm{kVA}$ or less: in accordance with IEEE 519

- For systems more than $300 \mathrm{kVA}$ : cannot exceed $5 \%$ of fundamental $60 \mathrm{~Hz}$ voltage or current waveform; a single harmonic cannot exceed $3 \%$ of fundamental frequency

\section{Specific Technical Interconnection Issues}

\section{Effect of Distributed Generation on Secondary Networks}

LIPA prohibits the interconnection of distributed generation on secondary networks with network protectors to prevent a reverse current situation. Although some utilities have more experience with network protectors and do allow distributed generation to interconnect, LIPA believes that the effect of distributed generation on these secondary networks has not been sufficiently studied and does not wish to risk potential damage to its system.

\section{Effect of Distributed Generation Penetration on the Grid}

Another area for further study is the effect of a greater penetration of generators on the grid. There is a need to better understand how multiple machines of various technologies could island and could affect voltage and frequency. 


\section{Local Work Methods}

In some cases, the local work methods used by utilities may require additional interconnection protection schemes, such as direct transfer trip and SCADA monitoring and control. For example, live line restoration is a normal work procedure at LIPA. During live line restoration, linemen work on a line that has been disconnected from the system via an open substation breaker but not grounded. This type of work necessitates additional protection schemes such as direct transfer trip and SCADA ensure the safety of the linemen.

\section{Specific Business/Regulatory Interconnection Issues}

None was noted. 


\section{Pacific Gas and Electric}

Utility

San Francisco, California

www.pge.com

John Vardanian, senior project manager, Interconnection Services（jav7@pge.com)

Jerry Jackson, senior tariff analyst, Tariffs and Compliance: grj4@pge.com

Patrick Wong: pxwe@pge.com

\section{Background}

Pacific Gas and Electric (PG\&E) provides utility service to 70,000 square miles of central and northern California.

\section{Distributed Generation Installed in Territory}

PG\&E saw a rush of interconnection requests during the spring of 2001 as the California energy crisis took full effect, but this rush tapered off by the end of 2001. Most of the distributed generation installations in its territory have been internal combustion engines, though microturbines are gaining popularity. Overall, PG\&E has 1.3 MW of PV, $6 \mathrm{MW}$ of natural gas combustion engines, and $65 \mathrm{MW}$ of natural gas combustion turbines installed in its territory. PG\&E also has 1,700 small (less than $10 \mathrm{~kW}$ ) distributed generation projects installed in its territory.

\section{Interconnection Requirements}

As a California investor-owned utility, PG\&E is subject to Rule 21 for the interconnection of distributed generation. Rule 21 is an ongoing process mandated by the California Public Utilities Commission to define a consensus, stakeholder-driven protocol for distributed generation interconnection.

\section{Interconnection Costs}

As is the case for all utilities subject to Rule 21, interconnection applicants are subject to an $\$ 800$ initial review fee. After this review, PG\&E decides whether to require a supplemental review (which costs \$600) and a detailed study. Timeframes and costs for the initial and supplemental review are strictly set under Rule 21 . PG\&E is currently participating in a California Energy Commission-funded study to determine what the true costs of these reviews are to the utility.

\section{Major Technical Requirements}

\section{Power Electronics}

PG\&E asks for UL certification of equipment connected with its grid. As distributed generation installations increase, PG\&E is seeing more applications for non-certified equipment. A national testing laboratory must certify non-certified equipment before it can be used for interconnection. 


\section{Voltage Requirements}

PG\&E requires systems $11 \mathrm{kVA}$ or less to operate at $106-132 \mathrm{~V}(88 \%-110 \%$ of nominal 120 $\mathrm{V}$ base). For systems larger than $11 \mathrm{kVA}, 88 \%-110 \%$ of appropriate interconnection voltage is required, though $\mathrm{PG \& E}$ may require adjustable operating voltage settings.

Voltage trip requirements (at nominal $120 \mathrm{~V}$ ):

- Less than $60 \mathrm{~V}: 10$ cycles

- $60 \mathrm{~V}$ to $106 \mathrm{~V}: 120$ cycles

- $132 \mathrm{~V}$ to $165 \mathrm{~V}$ : 120 cycles ( 30 cycles for systems larger than $11 \mathrm{kVA}$ )

- More than $165 \mathrm{~V}: 6$ cycles

Frequency Requirements

For systems $11 \mathrm{kVA}$ or less:

- $59.3 \mathrm{~Hz}$ to $60.5 \mathrm{~Hz}: 10$ cycles

For systems larger than $11 \mathrm{kVA}$ :

- PG\&E may require adjustable operating frequency settings

Power Factor

0.9 leading or lagging

\section{Harmonics}

Compliance with IEEE 519

\section{Specific Technical Interconnection Issues}

\section{Islanding}

PG\&E noted that it has not experienced problems with islanding so far. The requirements of Rule 21 provide good protection against islanding situations, and UL 1741 was described as a "tight" test.

At one point, PG\&E had an issue with a particular inverter used for PV applications. The inverter did not properly provide anti-islanding protections, a condition that was exacerbated by minimum conditions. A software patch was able to fix the problem.

\section{Effect of Distributed Generation on Networks}

PG\&E has been cautious with distributed generation installed on networked systems. It noted that some customers are not aware of how a network system works and are not taking the particular needs of a network system into their interconnection design. 
For distributed generation interconnections on networked systems, PG\&E requires network protectors to prevent backfeed onto the system from the load side. PG\&E also requires the installation of an under power device to ensure a minimum level of power is being imported to the system to prevent backfeed. PG\&E has not yet experienced a situation in which a distributed generator caused backfeed onto a network.

\section{Effect of Distributed Generation on Power Quality}

PG\&E is also working with the California Energy Commission to study the effect of distributed generation on the overall transmission and distribution system from the supply side. They hope to better understand where distributed generation resources can best be placed in the system and the power quality effects of distributed generation on the system. At the time of writing, it was anticipated that this report would be released in January 2003.

\section{Specific Business/Regulatory Interconnection Issues}

\section{Stakeholder Education About Distributed Generation}

The size of PG\&E's distribution planning area means that the utility has many far-flung field offices that are less familiar with distributed generation. To better respond to the need for timely and cost-effective interconnections, PG\&E is working to educate the field offices and other stakeholders involved in the distributed generation interconnection process. 


\section{San Diego Gas \& Electric}

Utility

San Diego, California

www.sdge.com

Michael Iammarino, senior energy administrator: miammarino@sdge.com

\section{Background}

San Diego Gas \& Electric (SDG\&E) provides utility service to the greater San Diego metropolitan area.

\section{Distributed Generation Installed in Territory}

SDG\&E has approximately $10.5 \mathrm{MW}$ of customer-owned distributed generation connected with its grid. Distributed generation technologies are listed in the table below.

Table A-1. San Diego Gas \& Electric Distributed Generation Installations

\begin{tabular}{lcc}
\hline \multicolumn{1}{c}{ Technology } & Installations & Total Capacity (kW) \\
\cline { 2 - 3 } Natural Gas-Fired & 11 & 990 \\
Microturbines & 12 & 5,000 \\
Natural Gas-Fired Internal & & \\
$\begin{array}{l}\text { Combustion Engines } \\
\text { Net Metered Technology }\end{array}$ & 641 & 2,895 \\
(Primarily PV) & 4 & 1,629 \\
Other & 4 & \\
\hline
\end{tabular}

All distributed generation installations of $2 \mathrm{MW}$ or less can interconnect with the SDG\&E distribution system, eventually connecting with the transmission grid through a distribution transformer with a grid voltage of $12 \mathrm{kV}$. Distributed generation units are connected behind the customer meter, and output varies from $120 \mathrm{~V}$ and up.

\section{Interconnection Requirements}

As a California investor-owned utility, SDG\&E is subject to Rule 21 for the interconnection of distributed generation. Mandated by the California Public Utilities Commission, Rule 21 is an ongoing process to define a consensus, stakeholder-driven protocol for distributed generation interconnection.

\section{Interconnection Costs}

As is the case for all utilities subject to Rule 21, SDG\&E interconnection applicants are subject to an $\$ 800$ initial review fee. After this review, SDG\&E decides whether to require a supplemental review (which costs $\$ 600$ ) and a detailed study. No distributed generation installation in SDG\&E territory has undergone a detailed study. 
Timeframes and costs for the initial and supplemental review are strictly set under Rule 21 . A typical review process takes upwards of 10 days, and no review has taken more than 20 business days.

\section{Major Technical Requirements}

\section{Power Electronics}

SDG\&E requires that all power electronics meet Rule 21 specifications.

\section{Voltage Requirements}

SDG\&E requires systems $11 \mathrm{kVA}$ or less to operate at $106-132 \mathrm{~V}(88 \%-110 \%$ of nominal $120-\mathrm{V}$ base). For systems larger than $11 \mathrm{kVA}, 88 \%-110 \%$ of appropriate interconnection voltage is required, though $\mathrm{SDG} \& \mathrm{E}$ may require adjustable operating voltage settings.

Voltage trip requirements (at nominal $120 \mathrm{~V}$ ):

- Less than $60 \mathrm{~V}: 10$ cycles

- $60 \mathrm{~V}$ to less than $106 \mathrm{~V}: 120$ cycles

- More than $132 \mathrm{~V}$ to $165 \mathrm{~V}: 120$ cycles (30 cycles for installations larger than $11 \mathrm{kVA}$ )

- More than $165 \mathrm{~V}: 6$ cycles

\section{Frequency Requirements}

For systems $11 \mathrm{kVA}$ or less:

- $\quad 59.3 \mathrm{~Hz}$ to $60.5 \mathrm{~Hz}$ : 10 cycles

For systems larger than $11 \mathrm{kVA}$ :

- SDG\&E may require adjustable operating frequency settings

Power Factor

0.9 leading or lagging

\section{Harmonics}

Compliance with IEEE 519

\section{Specific Technical Interconnection Issues}

SDG\&E has not encountered any specific technical issues with interconnecting distributed generation with the grid.

\section{Specific Business/Regulatory Interconnection Issues}

SDG\&E has not encountered any specific business or regulatory issues with interconnecting distributed generation with the grid. 
Southern California Edison

Utility

Rosemead, California

www.sce.com

Scott Lacy, distribution engineer, Network Engineering: scott.lacy@sce.com

Ed Grebel: ed.grebel@sce.com

Tom Dossey, contract manager, QF Resources: thomas.dossey@sce.com

\section{Background}

Southern California Edison (SCE) is a major investor-owned utility that serves portions of southern and central California, including much of the greater Los Angeles metropolitan area.

\section{Distributed Generation Installed in Territory}

Prior to the "deregulation" of California's electric utilities in 1998, SCE's customers had installed and interconnected more than 300 distributed generation-type systems under the provision of the 1978 Public Utilities Regulatory Policies Act. In the past two years, SCE has allowed the interconnection of nearly 1,000 small (less than $10 \mathrm{~kW}$ ) solar or wind-powered generating systems and approximately 150 larger generating facilities ranging from $30-\mathrm{kW}$ microturbines to 50-MW multiunit generating facilities.

\section{Interconnection Experience}

As an investor-owned utility in California, SCE is subject to the regulation of the California Public Utilities Commission and has filed its version of Rule 21 to establish rules and technical requirements for retail customers interconnecting distributed generation with the grid. The adoption of a revised and common Rule 21 has allowed SCE to update its interconnection standards and match its requirements with those of other California investorowned utilities.

The update and revision of Rule 21 was a collaborative process among key stakeholders of the distributed generation community, utilities, and regulators in California. The new provisions of the rule have clarified, standardized, and simplified the process whereby a utility customer may interconnect a generator to supplement the retail service it receives from a California utility.

SCE maintains an open-grid policy; anyone can interconnect generation with the grid provided they comply with the California Public Utilities Commission's approved interconnection processes and requirements.

\section{Interconnection Costs}

As is the case for all utilities subject to Rule 21, SCE interconnection applicants are subject to an $\$ 800$ initial review fee. After this review, SCE decides whether to require a supplemental review (which costs \$600) and a detailed study. Time frames and costs for the initial and supplemental review are strictly set under Rule 21 . 
Under the Rule 21 application process, SCE estimates that $90 \%$ of all interconnection applications are approved after the supplemental review. Five percent pass after the initial review, and another 5\% require a more detailed interconnection study.

\section{Technical Interconnection Requirements}

SCE's interconnection requirements primarily address the effect that a customer's generation facility may have on the safe and reliable operation of SCE's distribution system. The interconnection equipment must be able to detect and clear itself from faults on SCE's distribution system and prevent the generator from energizing a de-energized portion of the utility system. In addition, the distributed generation must not degrade the level of service SCE provides to its other customers. However, generally, power quality problems associated with distributed generators have not been a significant issue for SCE.

Under Rule 21, SCE requires customers to install visible disconnect devices between their generating facilities and SCE's system to ensure the safety of personnel working on the utility's equipment. For most customer generation installations, SCE's representatives will observe and review the results of the "commissioning tests" required under the rule.

\section{Power Electronics}

Rule 21 allows utilities to accept UL (or other nationally recognized testing laboratories') certification of power electronics. Many of the interconnection requirements set forth in Rule 21 are based on the requirements established in UL 1741 testing criteria.

\section{Voltage Requirements}

SCE requires systems $11 \mathrm{kVA}$ or less to operate at $106-132 \mathrm{~V}(88 \%-110 \%$ of nominal $120-\mathrm{V}$ base). For systems larger than $11 \mathrm{kVA}, 88 \%-110 \%$ of appropriate interconnection voltage is required, though SCE may require adjustable operating voltage settings.

Voltage trip requirements (at nominal $120 \mathrm{~V}$ ):

- Less than $60 \mathrm{~V}: 10$ cycles

- $60 \mathrm{~V}$ to less than $106 \mathrm{~V}: 120$ cycles

- More than $132 \mathrm{~V}$ to $165 \mathrm{~V}$ : 120 cycles (30 cycles for installations larger than $11 \mathrm{kVA}$ )

- More than $165 \mathrm{~V}: 6$ cycles

\section{Frequency Requirements}

For systems $11 \mathrm{kVA}$ or less:

- $59.3 \mathrm{~Hz}$ to $60.5 \mathrm{~Hz}: 10$ cycles

For systems larger than $11 \mathrm{kVA}$ :

- SCE may require adjustable operating frequency settings

Power Factor

0.9 leading or lagging 
Harmonics

Compliance with IEEE 519

\section{Specific Technical Interconnection Issues}

Complexity of the Utility Grid Makes Plug-and-Play Interconnection Difficult

One of the chief problems encountered by utilities in the establishment of interconnection standards such as Rule 21 is that utility grids are composed of relatively complex and varying systems that include many voltages and technologies. This complexity makes it difficult to develop and apply standardized "plug and play" interconnection criteria.

\section{Specific Business/Regulatory Interconnection Issues}

\section{Customer Education About Distributed Generation Issues}

SCE believes the most important factors of creating a smooth and timely interconnection process are the experience and knowledge of the applicants and their utility counterparts. Working with the various parties installing generation for its customers, SCE has observed that it usually takes two to four installations before this experience and knowledge are gained by a system integrator or customer. Instrumental in this process is learning the importance of verifying an applicant's understanding of a utility's interconnection requirements and developing realistic timing expectations early in the development process. Currently, it appears that interconnection requirements are often among the last thing a developer considers. Such inattention to this necessary step often creates unnecessary conflict and revisions of interconnection designs. Utility system voltage levels, design, and capacity may not appear to be important factors to the project developer, but such factors can be problematic for the utility.

The utility noted that interconnection requirements are very dependent on the capacity and type of generation being installed as well as on the capacity and design of the utility system at the point of interconnection. Because certain locations in the system require more effort and cost for interconnection, involving the utility earlier in the process makes it more likely the interconnection will go smoothly.

\section{Mandated Rule 21 Application Fees}

SCE believes that the interconnection fee structure established under Rule 21 is not adequate to cover its true cost of reviewing and administrating interconnection applications. SCE is in the process of tracking its true costs to determine whether it meets the targets mandated under Rule 21. 


\section{A.3.2 Customer/Manufacturer/Developer Interviews}

Through the course of this project, Sentech interviewed manufacturers, installers, and customers using small wind turbine, fuel cell, microturbine, PV, and cogeneration systems.

\section{Alternate Energy Corp.}

Distributed generation installer

Cumberland, Rhode Island

Tom Aubee, president: taubee@att.net

\section{Background}

Alternate Energy Corp. (AEC) is a subsidiary of Valley Resources. The company installs and services a wide variety of distributed generation technologies.

\section{Distributed Generation Installed}

AEC was hired by the University of Connecticut to install a 200-kW UTC solid oxide fuel cell during 2002 at the university's main campus in Storrs, Connecticut. The fuel cell, which is used primarily for teaching purposes, services a $130-\mathrm{kW}$ load. It does not attempt to gain optimal efficiency by using the thermal output of the fuel cell.

\section{Interconnection Experience}

The utility for the site, Northeast Utilities, provided the technical requirements for interconnection to AEC. To interconnect with the grid, AEC used a Beckwith Pride relay with zero export control.

The utility's required interconnection settings included:

- Under voltage: 120 cycles at $80 \%$ (or $384 \mathrm{~V}$ )

- Over voltage: 15 cycles at $120 \%$ (or $576 \mathrm{~V}$ )

- Under frequency: 60 cycles at $59.5 \mathrm{~Hz}$

- Over frequency: 60 cycles at $60.5 \mathrm{~Hz}$.

The utility also required observation of the calibration of settings, trip test of the relay functions, and witnessing the polarization of the reverse current relay.

In general, AEC felt that although utilities do not want to be perceived as impeding the progress of renewables and clean energy, they are not focused on facilitating distributed generation interconnection. AEC noted that utilities are generally focused on preventing islanding and that it is often utility policy to ground all three phases on a line that has a fault, which will cause any distributed generators operating on that line to stop operating.

\section{Specific Technical Interconnection Issues}

AEC noted that the utility's technical interconnection requirements were not onerous. 


\section{Specific Business/Regulatory Interconnection Issues}

\section{Third-Party Inspector Pre-Certification}

The fuel cell in question had been previously installed at another location within the utility's service area. All interconnection approvals had been granted by the utility at that site. Despite this, the utility required AEC to bring in a third-party inspector to test the interconnection again at the new site. This inspection included calibration of settings and conducting a trip test. AEC was required to pay the cost of the inspection (approximately \$10,000). AEC noted that the utility had not established a list of qualified third-party inspectors, which added cost and delay by forcing AEC to find an inspector and certify it with the utility prior to performing the inspection. 


\section{Bergey Windpower}

Small wind turbine manufacturer

Norman, Oklahoma

www.bergey.com

Mike Bergey, president: mbergey@bergey.com

\section{Background}

Bergey Windpower provides small wind turbines $(1-10 \mathrm{~kW})$ in the United States. Bergey has been installing small wind turbines for 25 years and has considerable interconnection experience in $10-\mathrm{kW}$ and smaller systems.

\section{Distributed Generation Installed}

This information was not available.

\section{Interconnection Experience}

It was noted that a "typical" interconnection experience has not yet evolved on a national scale. Some utilities view interconnection as a normal part of business. These utilities often do business in states that have passed net metering provisions, and frequently the entire interconnection process can be completed via phone. Oklahoma Gas and Electric, Oklahoma Electric Cooperative, and Public Service of Oklahoma were cited as examples of utilities that operate in this fashion.

Approximately $90 \%$ of Bergey's interconnections go smoothly. The average interconnection process adds costs in the hundreds of dollars for a typical Bergey Windpower installation. The majority of this cost is in the labor hours required to navigate the interconnection process.

Because much of IEEE 1547 is covered under the UL 1741 standard, which Bergey Windpower's products already meet, Bergey does not believe the passage of IEEE 1547 will have much effect on the company's interconnection issues. Existing inverter standards should continue to apply. Bergey's principal concern with the passage of IEEE 1547 was that it might make interconnection more difficult by reducing the presumption of safety in interconnection technology. For IEEE 1547 to be effective, Bergey believes that it must become a symmetrical standard that utilities must comply with, rather than a minimum that utilities can raise standards above.

In Bergey Windpower's experience, interconnection barriers are not the primary impediment to the growth of the distributed generation market. The economics of distributed generation is the primary impediment. 


\section{Specific Technical Interconnection Issues}

\section{Anti-Islanding Requirements}

Bergey believes that further work is needed to examine how realistic anti-islanding requirements are and to ensure that anti-islanding requirements are based on real-world, rather than laboratory, situations.

More utilities are requiring IEEE and UL standards for distributed generation interconnection. This is good for distributed generation because it provides a universal performance baseline for power electronics and other interconnection devices. Bergey has a concern that the requirements included in IEEE and UL standards are often so stringent that manufacturers must invest large amounts to comply with them even though the situations that necessitate these standards are often impossible to replicate outside of a laboratory. Specific examples Bergey cited are the anti-islanding provisions in IEEE 929 and UL 1741.

\section{Compliance of Loads and Utilities With IEEE 519}

Bergey believes that a study could be done to examine compliance with IEEE 519 from load and utility perspectives. IEEE 519 currently requires generators to meet certain standards for the power they deliver to the grid, and these requirements substantially raise the cost of inverters in the $1-10 \mathrm{~kW}$ range. However, IEEE 519 does not require the utility to deliver power at these same standards or the customer load to meet these standards.

\section{Specific Business/Regulatory Interconnection Issues}

\section{Consistency of State and National Interconnection Standards}

Bergey Windpower's interconnection experience in states with interconnection standardssuch Texas, California, and New York - has proved mostly positive because statewide interconnection standards typically ease the interconnection process. One issue is that, in some states - including New York and Texas - interconnection standards are not consistent with UL and IEEE requirements. In Texas, for example, the state requires fault set points for over/under voltage that do not coordinate with IEEE 929-2000 and UL 1741 standards. This forces the installer to obtain a waiver from each utility on this requirement. New York's standard requires seven anti-islanding tests beyond those specified in UL 1741 and IEEE 929-2000.

Although this lack of uniformity across states creates some difficulty, it was noted that the pre-certification process for equipment makes the interconnection process easier. For example, a utility in New York had previously required a \$7,000 protective relay for a Bergey Windpower installation. Mr. Bergey noted that the protective relay was never technically justified; the utility merely insisted on its use. With the institution of pre-certification, these extra protective relays are no longer required by the utility. 
Consistency Across Utilities Subject to the Same Interconnection Standards

Bergey also noted that there is often a lack of consistency across utilities subject to the same interconnection standards. Utilities sometimes interpret the same standard in different ways, which increases the difficulty of interconnection. For example, in California, PG\&E requires a disconnect switch within $10 \mathrm{ft}$ of the service entrance, but SCE allows the required disconnect to be anywhere accessible to the utility. Both utilities are subject to the same interconnection requirements (Rule 21). Because Bergey Windpower's own standards require a fused disconnect switch at the base of the wind turbine tower, Bergey must install two disconnect switches in PG\&E territory, which adds $\$ 400-\$ 750$ to the cost of each PG\&E installation. $P G \& E$ refuses to alter its interpretation of this rule.

\section{Safety as a Mask for Anti-Competitiveness}

Overall, most interconnection issues are nontechnical. In Bergey's opinion, the major problem with interconnection is the anti-competitive attitude of utilities, masked as a concern for safety. Bergey believes that utilities have not been able to provide examples of distributed generation that have caused safety issues, equipment damage, or diminishing power quality. From this company's perspective, utilities sometimes place a long list of technical requirements on wind turbine interconnection and often continue to add technical requirements as the process goes along. These technical requirements appear to be unjustified and used only for anti-competitive purposes. 
BP Solar

Solar PV manufacturer

Fairfield, California

www.bpsolar.com

Kevin Davies, projects manager, Grid Connect Systems: davieskg2@bp.com

Paul Hutchinson, project engineer: hutchipa@bp.com

Chuck Sippel, field engineer

\section{Background}

BP Solar is a subsidiary of British Petroleum. It is one of the largest PV manufacturers in the world and has interconnection experience worldwide. BP Solar does much of its work on "BP Connect" service stations, which have PV integrated into their canopies.

\section{Distributed Generation Installed}

BP Solar has completed PV installation at approximately $160 \mathrm{BP}$ service stations nationwide. Its basic system is centered on a $10-\mathrm{kW}$ to $20-\mathrm{kW}$ canopy, though BP uses 17 different styles based on zoning requirements.

\section{Interconnection Experience}

BP Solar uses modified Xantrex ST 1500 and ST 2500 inverters. Several modifications have been made to the inverter. The GFI breaker has been reduced. Also, because the combiner board did not have capacity to accept all necessary wires, the fused combiner box was removed, and two large terminal blocks were installed, requiring a separate combiner box with fuses.

Although BP Solar designs and builds solar PV systems for BP service stations, the actual interconnection and permitting process is performed by a BP contractor, with BP Solar providing technical expertise.

Generally, BP Solar finds that gaining interconnection approval from the utility takes longer than building and installing the system. Based on its experience, the demarcation between easy and difficult interconnections falls at roughly $10 \mathrm{~kW}$. Overall, about $65 \%$ of the completed BP Connect sites have actually been interconnected and turned on. The remaining sites have been held up in large part because of interconnection issues. On the positive side, $\mathrm{BP}$ has found that once the first site has been established in a utility's area of operations, other sites in the same jurisdiction generally have an easier time interconnecting with the grid.

BP Solar estimates that interconnection studies can account for $10 \%$ or more of the cost of a large (1-MW) system. It does not have specific cost information for the smaller systems installed at gas stations. Given the large cost associated with proving that its power electronics and inverter provide the necessary protection, BP Solar is advocating the creation of a single nationwide certification system to demonstrate to an inspector or a protection engineer that an inverter meets all technical requirements for interconnection. 
BP Solar noted that interconnection experiences vary widely by utility. In Indianapolis, for example, BP has successfully interconnected eight systems without difficulty. These systems are all 10-20 kW and connected on the load side to serve on-site load. In New York, where system size is $10-15 \mathrm{~kW}$, BP Solar experienced more difficulty. The company initially installed a system and received interconnection approval from the local utility. However, after the manufacturer of BP Solar's inverter upgraded the software on the inverter, the local utility decided to shut down the site to gain a better understanding of how the software functioned. The inverter manufacturer was able to provide information to the utility to regain approval to operate. This was the only incident of its type with this particular utility, and since then, BP Solar has switched on systems in the utility's area without incident.

\section{Specific Technical Interconnection Issues}

\section{Utility Safety Concerns}

In BP Solar's experience, the greatest concern for most utilities is safety. Utilities consistently want to see a physical relay and disconnect for each interconnection. Demonstrating the grounding of PV systems is a big problem for BP Solar. Many utilities also want to see charts and plots of voltage decay. DC disconnect ratings are also a problem because the UL certification is primarily a power supply rating and, as such, does not address PV. BP Solar is still working to resolve this problem.

\section{Specific Business/Regulatory Interconnection Issues}

\section{Education of Utility Employees}

BP Solar also spends much of its time educating the technical community about how PV systems work, how PV systems interconnect with the grid, and solar safety. This education is focused on engineers and account representatives at utilities as well as contracting electricians.

\section{Inconsistency of State and National Interconnection Standards}

The inconsistency of state interconnection requirements and national interconnection standards complicates the interconnection process. For example, Texas was noted as a difficult state to interconnect in for one reason: the state's interconnection standards require an automatic disconnect at $+5 \%$ or $-10 \%$ of nominal voltage, which is more stringent than IEEE 1547 or UL standards. Inverter manufacturers will not pay for certification at this more stringent level, which forces BP to certify each system with the utility separately and adds cost to each installation. In Houston, for example, the utility requires a balanced load test at the supply point and is planning to use a programmable load/synthetic utility system to carry out this test. 


\section{Capstone Turbine}

Microturbine manufacturer

Chatsworth, California

www.microturbine.com

David McShane, vice president, Quality Deployment and Customer Service:

dmcshane@capstoneturbine.com

Bryan Fox, manager, Product Reliability: bfox@capstoneturbine.com

\section{Background}

Capstone is a microturbine manufacturer. Capstone's microturbines are currently produced in $30-\mathrm{kW}$ and $60-\mathrm{kW}$ models.

\section{Distributed Generation Installed}

Capstone has shipped more than 2,500 microturbines (between 80 and $90 \mathrm{MW}$ ). It has interconnection experience worldwide. Capstone typically partners with other companies for installation and service of its turbines and provides training and support for these companies.

The firmware in each microturbine includes protective relays, which provide protection for over/under voltage, over/under frequency, anti-islanding, and reverse power flow (with the use of an external power meter). The firmware is installed on the "Power Controller," which is a device that includes two three-phase inverters, power conditioning equipment, and a system controller. The Power Controller follows the prevailing grid frequency and voltage when interconnected. Because the Power Controller is inverter-based, fault currents are limited to the maximum current rating of the microturbine. Capstone's power electronics meet UL 1741 standards and, as such, fall below IEEE 519 standards for harmonic distortion.

\section{Interconnection Experience}

Capstone noted that the average time for interconnection has generally decreased, particularly in California, Texas, and New York, each of which have a well-established interconnection procedure. Utilities generally accept UL listing for islanding protection. Capstone's microturbines meet UL 1741 standards and can respond to all of the issues addressed under the IEEE 1547 standard. Capstone has found that utility requirements for protection parameters are not tight and are often less restrictive than UL 1741 or IEEE 1547 standards.

\section{Specific Technical Interconnection Issues}

\section{Standardized On-Site Performance Testing of Power Electronics}

In Capstone's experience, utilities are generally concerned with making sure that protective relays on a DER installation work properly and usually want to see this demonstrated. On-site performance testing of power electronics has been one interconnection issue faced by Capstone. Capstone noted that at a recent installation at a Fairfield, Connecticut, wastewater treatment plant, the utility accepted Capstone's internal relays but was unable to conduct the testing of Capstone's power electronics quickly enough to satisfy the customer, who chose to install external relays to hasten the interconnection process. 
In response to this issue, Capstone has developed a standardized testing interface, the Protective Relay Test Adapter, that allows utilities to easily perform on-site testing. This device tests the level and timing accuracy of the relays for over/under voltage and over/under frequency. This allows relatively inexpensive testing of interconnection settings and performance (typically $\$ 500-\$ 2,000$ per day of testing required).

\section{Anti-Islanding Testing for Multi-Unit Installations}

Capstone noted that it often installs its microturbines in "multi-pack" installations. Antiislanding is a concern to utilities with these installations because it is not generally understood how the units interact with one another or the grid. Capstone has developed a server to control multi-packs and believes that this server could serve as the basis for a universal interconnection device.

\section{Effect of Distributed Generation Penetration on Feeders}

Capstone noted that, with the proliferation of distributed generation on the grid, situations will arise in which distributed generation is the majority of the power on a feeder. Tests need to be done to determine how this situation can be dealt with without compromising the performance of the feeder.

\section{Specific Business/Regulatory Interconnection Issues}

\section{Tariffs}

Capstone noted that from a nontechnical perspective, tariffs, particularly disconnect and interconnect fees, are a significant barrier to interconnection. Interconnection in the United States still remains a difficult process compared with interconnection in other countries, including Japan and Great Britain, that have national interconnection standards. The primary differences between the United States and other countries are the business and regulatory aspects of interconnection (i.e., standby charges and exit fees).

\section{Statewide and Nationwide Interconnection Standards}

Capstone participates in the Rule 21 process in California and described this as a reasonable approach to interconnection. The multistep process allows all parties to know exactly what standard to aim for. In Capstone's opinion, Rule 21 is the best of the California, Texas, and New York standards. Capstone's opinion is that creation and enforcement of a national interconnection standard must come from the top down, beginning with the utilities, and probably should not include a universal "black box."

\section{Education of Protection Engineers}

To facilitate the interconnection process, Capstone is educating protection engineers and other decision makers who are required to deal with distributed generation. In this vein, Capstone regularly participates in the Department of Energy's Distributed Energy Road Shows, which are workshops that educate local code officials about various distributed generation technologies and installation issues. 
More frequently, education occurs when a customer attempts to install a microturbine, and Capstone must educate the local protection engineer about the performance aspects of the microturbine, typically by showing UL documentation. Certification of equipment on a statewide level in states such as California, Texas, and New York makes this easier, but most states do not offer such certifications. In these states, interconnections must be dealt with on a case-by-case basis, which is more time-consuming. 
Cordis Corp.

Medical device manufacturer

Warren, New Jersey

www.cordis.com

Stephen DuBarry, CPE, senior facility engineer: sdubarry@crdus.jnj.com

\section{Background}

Cordis Corp., a Johnson \& Johnson company, produces surgical devices for the management of vascular diseases.

\section{Distributed Generation Installed}

Cordis contracted with PowerLight Corp. to install a 72-kW PV system using Solarex panels and a Xantrex inverter. The system produces 208 VAC three-phase, which is stepped up to $480 \mathrm{~V}$.

\section{Interconnection Experience}

Cordis made the decision to install a solar PV system at its Warren, New Jersey, facility after consultation with Johnson \& Johnson's corporate energy group. Cordis applied to interconnect with the local utility, Jersey Central Power \& Light.

The utility's required interconnection settings were based on the net metering, safety, and power quality standards of the New Jersey Board of Public Utilities for systems less than 100 $\mathrm{kW}$. This required the system to meet applicable safety and power quality standards, including IEEE 929 (a standard for PV systems) and UL 1741.

Jersey Central Power \& Light's biggest concern was backfeed off of the inverter and onto the grid. The utility did require the installation of a visible disconnect switch that is available 24 hours a day outside the building. In addition, the inverter used in the system is set to shut down if it does not detect power from the grid, making it impossible for the system to operate in an islanded or standalone mode. Although the inverter is designed to automatically synchronize with the grid, the installation contractor performed some phase checking to ensure that the system would properly synchronize.

Total system cost was approximately $\$ 550,000$, of which Cordis paid approximately $\$ 142,000$. The rest was paid for by grants for renewable energy and sustainable development from states and the federal government.

Since the system was turned on, neither Cordis nor the utility has encountered any major operational issues with the system's performance.

\section{Specific Technical Interconnection Issues}

None was noted. 


\section{Specific Business/Regulatory Interconnection Issues}

Responsiveness of the Utility

Cordis had minor problems receiving permission from the utility to turn on the system.

Despite the fact that Cordis had applied for interconnection weeks before the system was due to come online, the company had difficulty receiving any response from the utility regarding the status of the interconnection. The cause of this delay was not clear. Cordis finally received approval to turn the system on without a final interconnect inspection, which was performed by the utility after the fact. 


\section{Cummins Engine}

Generator manufacturer

Minneapolis, Minnesota

www.cummins.com

Gary Olson: gary.1.olson@cummins.com

\section{Background}

Cummins Engine builds reciprocating synchronous diesel-fired generator sets and natural gasfired generator sets.

\section{Distributed Generation Installed}

Cummins builds units ranging from $30 \mathrm{~kW}$ to $2 \mathrm{MW}$. It produces approximately 10,000 units a year, with the greatest volume in the range of $30 \mathrm{~kW}$ to $200 \mathrm{~kW}$. A typical Cummins system consists of multiple engines with total capacity in the range of $500 \mathrm{~kW}$ to $4 \mathrm{MW}$ for commercial or industrial applications. Typical uses are for interruptible applications (i.e., rate reduction, soft transfer, cogeneration, and backup power).

\section{Interconnection Experience}

Cummins has completed thousands of interconnections, most using the same protective functions. Its interconnection experience varies by utility. In general, Cummins has found that if a utility wants a company to install distributed generation at a particular point on the grid, the interconnection process goes smoothly. Cummins generally tries to work with the utility as a partner and install the protection the utility wants.

In Cummins' experience, typical protection systems required by the utility cost less than $\$ 10,000$ - a cost that can be easily absorbed by the installation. Utility protection requirements typically include a utility-grade over/under voltage and phase sequence relay, an over/under frequency relay, and a reverse power relay. Given the fact that the time from order to installation of a Cummins system typically takes up to a year, there is always adequate time to handle all interconnection requirements.

Cummins also distributes Capstone turbines. It has not encountered significant problems with the interconnection of these systems, perhaps because the smaller size ( $30 \mathrm{~kW}$ and $60 \mathrm{~kW})$ does not attract the attention of utilities. This could also be because it has not been distributing the turbines for a long time.

Cummins has found California, Chicago, and Florida to be particularly difficult territories for the interconnection of its products. Texas was noted as a state in which the interconnection standard seems to be working well. 


\section{Specific Technical Interconnection Issues}

\section{Unrealistic Anti-Islanding Standards}

Cummins has found that the biggest technical issue with the IEEE 1547 standard is antiislanding. Although the actual probability that a person will be hurt by an islanding condition is small and modern control systems largely deal with the problem, Cummins has found that utilities focus on this issue. Currently, the IEEE 1547 standard requires an anti-islanding trip in 2 seconds, which the interviewee believes may be unrealistic. A slower standard, perhaps 10 seconds, could provide protection to linemen while imposing less challenging requirements on protective equipment.

\section{Proper Settings for Protective Devices}

Finding proper settings for protective devices remains a problem. Cummins feels that, in many cases, who has the responsibility to set and test protective devices has not been clearly established. As an equipment supplier, Cummins does not have enough information about the needs of the utility to properly set its protection devices. In the absence of instruction from the utility, Cummins is forced to use conservative defaults, which are determined on a case-bycase basis by the engineer on site. Using conservative defaults hampers operation of the distributed generation device by forcing the device to trip more frequently than necessary, which reduces the reliability of the system.

\section{Nuisance Trips Caused by Grid}

Most operational problems associated with interconnection have more to do with the customer losing power to protect the grid than with damage to the grid itself. There has never been a reported incident of any damage to utility equipment by Cummins equipment. By installing a utility protection system, Cummins protects the utility from damage by the generator, but the customer remains vulnerable to power cutoffs. This places the needs of the consumer below the needs of the grid.

\section{Specific Business/Regulatory Interconnection Issues}

\section{Utility Interpretations of Interconnection Rules}

Cummins has found that interpretations of interconnection rules vary widely by utility. Cummins has found that many protective relay issues appear to be a matter of opinion and that individual utilities sometimes interpret the same state interconnection standard differently. For example, Cummins dealt with one utility that has a relay requirement for loss of synchronization. Typically, protections against loss of synchronization are designed to protect a large interconnected generator rather than the utility. However, this particular utility abides by the letter of the state's interconnection standards, which require such protection for generators of all sizes. It therefore required loss of synchronization protections on Cummins installations. Other utilities subject to the same standard have not required such protections. 


\section{State Interconnection Rules Open to Interpretation}

It was noted that state interconnection rules only specify what protective function must be met and are not sufficiently explicit in stating what protection equipment can be used to provide that function. This allows utilities to require the installation of more expensive equipment when inexpensive equipment might perform the same function.

For example in California, Cummins installed a 1.5-MW generator set primarily for backup purposes. Cummins installed utility-grade relays. Because the generator set would run momentarily in parallel (for 1 second), the utility required an independent relay from the control system to ensure that the system would trip in 1 second. Cummins believed that a pneumatic relay, which costs less than $\$ 10$, would meet the utility's requirement and suggested installing such a relay. Without providing a justification, the utility would not accept this relay, and it required that Cummins install a $\$ 2,000$ utility-grade relay to perform the same protective function. 
Hess Microgen

Cogeneration system integrator

Carson City, Nevada

www.hessmicrogen.com

Michael DeMarsi: demarsi@att.net

\section{Background}

Hess Microgen designs, builds, installs, owns, operates, and maintains customized packaged cogeneration systems nationwide.

\section{Distributed Generation Installed}

Hess Microgen's base unit is $200 \mathrm{~kW}$. However, at the time of writing, it had plans to introduce a $275-\mathrm{kW}$ and a $375-\mathrm{kW}$ unit late in 2002 . In the two years prior to the writing of this report, it produced approximately 250 units (totaling $40 \mathrm{MW}$ capacity). It owned, operated, and maintained 30 systems (totaling 5.3 MW capacity).

\section{Interconnection Experience}

Hess Microgen finds that utilities most often cite safety concerns when interconnecting Hess Microgen systems. In Hess's experience, utilities cite these safety concerns because distribution engineers don't understand how distributed generation will affect the grid. As transmission and distribution specialists, the utilities are not equipped to understand smallscale generation. Although the safety of linemen is of the utmost importance, linemen are subject to work safety rules imposed on them by insurance. These work safety rules, if properly followed, should prevent a lineman from being injured by islanding generation.

Hess Microgen has never been involved in a case of utility damage from a non-exporting interconnected generator. In the interviewee's opinion, damage caused by incorrect operation of units less than $500 \mathrm{~kW}$ will most likely occur to the distributed generator rather than to the grid.

Prior to the establishment of interconnection standards at the state level, Hess Microgen found that its distributed generation installations were generally approved by utilities because they were small $(60 \mathrm{~kW}$ to $75 \mathrm{~kW})$ and did not have much effect on the system. In the late $1990 \mathrm{~s}$, the expansion of distributed generation led some utilities to institute interconnection standards that were either lax or excessively stringent.

Regarding the IEEE 1547 standard, it was noted that the standard appears to be loose to gain acceptance from all stakeholders. One issue related to IEEE 1547 has to do with the Q-factor rating for anti-islanding, which IEEE 1547 sets at 2.5. It was noted that in some circumstances, when a generator intends to export power using a utility-grade inverter, this setting might need to be closer to 0.7. It was also noted that IEEE 1547's tripping requirements for over/under voltage (10 cycles) are extremely quick. 


\section{Specific Technical Interconnection Issues}

\section{UL 1741 as a Pre-Certification Standard for Rotational Generators}

The use of UL 1741 to pre-certify interconnection equipment was, at one time, a problem for cogeneration installers because UL 1741 is an inverter-based standard and does not cover rotational-based generators such as those used by Hess Microgen. This affected installations in states such as California that require UL 1741 listing as a pre-certification to streamline the interconnection process.

To alleviate the problem, Hess Microgen joined the UL 1741 committee to create a standard that could be used in Rule 21 and that would allow certification of the "utility interactive" portion of the standard. The process for certifying rotational generators under the UL 1741 standard was pioneered by Capstone Turbine.

While the standard was being created, PG\&E required redundant protection relays for systems that use multi-element relays because they did not qualify under UL 1741. Because of the sharp decrease in the cost of these items, Hess Microgen found it easier to comply with these utility requests than to attempt to fight the requirement.

The utility companies did not follow the streamlined approach to interconnection even after UL 1741 "certification" was achieved by Capstone. California utilities still required that extra tests be performed, and there was not significant time savings in meeting UL 1741 unless the installation was a small solar or wind technology. Only after Hess Microgen completed the utility interactive tests and submitted the results to the California Energy Commission were any significant time savings realized.

\section{Large Generator Interconnection Standards for Small Generators}

In California prior to the passage of Rule 21, some utilities applied interconnection standards for large independent power producers to small generators, which made it economically impossible for the small generators to comply. For example, PG\&E and SCE required that alternator data be provided for Hess Microgen installations. However, the data required were based on large generation, not the salient-pole alternators exclusively used by rotating machines less than $1 \mathrm{MW}$. These salient-pole alternators did not have values for items such as saturated quadrature-axis subtransient reactance that the utilities required the small generator to report.

In addition, the utilities wanted to run exhaustive unqualified studies with no pass/fail criteria before they would discuss interconnection. The costs of these unnamed studies were paid by the applicant, with no expectation of completion. In many cases, the costs would exceed the profitability of the cogeneration job. Even when the studies were complete, the data would not be made available to the interconnection applicant, who paid for the study. Therefore, there was no rebutting the findings. 
This system still exists in California if you are "thrown out" of the Rule 21 framework. It also exists in Consolidated Edison territory (New York City), where many projects costing no more than $\$ 5,000$ for design by a professional engineer are charged more than $\$ 15,000$ for review by the utility. In New York, Hess Microgen has operated without utility interconnects for some sites because the issues of cost and process were never resolved.

\section{Direct Transfer Trip Requirements}

Some utilities appear to be requesting the installation of a direct transfer trip for distributed generation interconnections without technical justification. For example, Hess Microgen worked with a hotel to install an $800-\mathrm{kW}$ synchronous system for base load operation. For this system, Hess installed its own relaying patterned on the requirements of a draft of IEEE 1547. The utility responded by requesting to see the physical disconnects and requesting the installation of a transfer trip. The utility also claimed that, because the installation used a Delta transformer primary but the circuit was a Y circuit, there was potential for the Delta system to not identify phase-to-ground faults when the breaker was open, which could damage the utility's lightning arrestors.

Hess Microgen argued that the average lighting strike is several million volts and several hundred thousand amperes. Arrestors are designed to handle this several times before failure. Hess Microgen calculated the highest possible current that the installation could contribute to the system for even a short duration. It was approximately $232 \mathrm{~A}$ (bolted three-phase fault) at $12,470 \mathrm{~V}$ at the primary side of the transformer (no distribution line losses). Hess Microgen noted that this could be possible only until the multiple thermalmagnetic breakers (which saw 6,220 A) and fuses would interrupt the circuit. This interruption time was calculated to be less than $20 \mathrm{~ms}$, or a little more than a cycle. This led Hess Microgen to believe that the utility's claim was unfounded.

The problem was solved by using the negative sequence voltage element included in the protective relay package in the Hess Microgen system. This element could pick up faults on the Delta as long as the utility breaker had not cleared the fault. Direct transfer trip, in contrast, would not have been useful in preventing this situation for any non-exporting protected generation system.

Hess Microgen believes that assumptions regarding infinite bus, multiple relay failures, and thermal-magnetic breaker and fuse failures often lead utilities to require direct transfer trip without technical merit. The "infinite bus" premise uses assumptions that are not true with small generation on a large power system. For example, a large utility grid system can sustain some level of faults on the distribution system indefinitely. In contrast, the prime mover that drives the small generator has little inertia and cannot sustain voltage or frequency during most overloads or faults.

\section{Nuisance Trips Caused by the Grid}

Hess Microgen has also experienced problems with nuisance trips caused by issues emanating from the grid. One Hess Microgen location in Hawaii experienced trips as the result of a failing utility substation transformer. The utility did not have the equipment necessary to detect these problems on the grid. The transformer eventually failed and caused a widespread outage. After the transformer was replaced, no further trips occurred. 


\section{Specific Business/Regulatory Interconnection Issues}

Standby Charges and Exit Fees

From a nontechnical perspective, it was noted that standby charges and exit fees erect barriers to interconnection. It was acknowledged that standby charges are necessary to compensate utilities for standby power on Hess Microgen installations, which typically run about $90 \%$ of the time. However, utilities are requiring customers on standby to pay $100 \%$ of the cost of spinning reserve rather than spreading the cost of maintaining spinning reserve across all generators on the grid (not unlike insurance premiums). Similarly, exit fees are charged to cogenerators that remove load from the grid, but they are not charged to other operations that remove load from the grid because of decreased demand (such as lighting retrofits) or the closing of a plant. 
Ingersoll-Rand Energy Systems

Microturbine manufacturer

Davidson, North Carolina

www.ingersoll-rand.com

Geoff Clark, national project manager: geoff_clark@irco.com

\section{Background}

Ingersoll-Rand is a diversified manufacturer of industrial and commercial equipment and components.

\section{Distributed Generation Installed}

Ingersoll-Rand Energy Systems has been selling its 70-kW PowerWorks microturbine since late 2001. At the time of writing, it had installed fewer than 100 microturbines.

\section{Interconnection Experience}

Ingersoll-Rand's microturbine has been sold mainly for commercial and industrial applications to provide combined heat and power, to provide green power, and for economic reasons. Installations are either induction or synchronous generators, and Ingersoll-Rand installs Beckwith M3410 (or other utility-preferred) protective relays at the point of common coupling. It typically connects to the customer facility distribution system at $208 \mathrm{~V}$ or $480 \mathrm{~V}$.

Interconnection costs for Ingersoll-Rand's microturbines vary by installation. Costs can include protective relay installations (which add approximately $\$ 5,000$ to the cost of an installation), capacitor banks (which cost from $\$ 1,500$ for fixed bank to $\$ 6,500$ for stepped filtered auto bank), and engineering studies (which cost $\$ 2,000$ to $\$ 4,000$ ). These costs are in addition to the mechanical and electrical components used in the installation (i.e., wire, switches, breakers, etc.).

Ingersoll-Rand's interconnection experience has varied by utility. Interconnections in California have generally gone smoothly because of Rule 21. Interconnections in other states, particularly in the Northeast, have faced more problems, primarily because the Northeast has more utilities and each has its own interconnection requirements.

\section{Specific Technical Interconnection Issues}

\section{Utilities Requirements of Capacitor Banks}

At one installation in the Northeast, Ingersoll-Rand received a written interconnection requirements document from the utility. This agreement defined the power factor requirements as a minimum of 0.85 at the point of common coupling after the generator was turned on. The agreement also included a provision that allowed the customer to buy reactive power from the utility on a monthly basis. This would have negated the need for a capacitor bank and the power factor protection. The customer planned to buy reactive power from the utility, but once it was made known to the utility, the utility refused to abide by the interconnection agreement and forced the customer to install capacitor banks to provide the power factor protection. This added cost to the project. 
Another Northeastern utility insisted on an additional control scheme for a capacitor bank system that resulted in additional design, hardware, and installation costs and delayed interconnection approval.

\section{Specific Business/Regulatory Interconnection Issues}

\section{Effect of Utility Charges on Project Economics}

At another installation in the Northeast, after interconnection was approved, the utility added competitive transmission charges. These competitive transmission charges were based on the customer's demand and rate schedule in a previous year even though the customer had reduced load and changed rate schedules in the interim. The customer disputed this charge because the competitive transmission charges would have added approximately $\$ 10,000 \mathrm{a}$ month to the cost of the project. The utility eventually agreed to use the current rate schedule for the exit fee calculation, which improved the economics of the project.

With one New York utility, Ingersoll-Rand has encountered charges for each kilowatt-hour generated by the microturbine. These charges are so great that they force Ingersoll-Rand installations in this area to operate independent of the grid.

\section{Utility Interconnection Contacts Difficult to Identify/Lack Knowledge}

In general, Ingersoll-Rand has found it difficult to identify the person at utilities to talk with regarding interconnection. Often, utility contacts are not knowledgeable about technical interconnection requirements. This forces Ingersoll-Rand to spend extra time communicating with the utility and slows down the interconnection process. Because protective relaying is such an important component of the interconnection process, it is important that the utility interconnection contact be conversant in relaying issues, but Ingersoll-Rand has found that knowledge in this area is often limited.

Ingersoll-Rand has found that once an appropriate contact at the utility has been identified, interconnection is usually approved, but it sometimes takes months to find that person. In addition, interconnection approval times can vary widely depending on who within the utility reviews the application.

\section{Varying Interconnection Standards and Requirements}

It was noted that interconnection standards vary widely from utility to utility and that this variation makes it difficult to standardize interconnection equipment and methods. Power factor correction requirements were noted to vary from utility to utility. Ingersoll-Rand noted that a national standard for power factor correction would be beneficial and that California's standard (0.9 lagging and 0.9 leading) is a good standard to follow.

Another issue is that preferred or approved protective relays and isolation schemes vary among utilities. Although the Beckwith M3410 used by Ingersoll-Rand technically satisfies protective isolation requirements, some utilities do not yet have it on their "approved" relay list. Other utilities that have already approved the Beckwith relay for use may prefer another relay based on the utility's interconnection experience. As a result, the utility may delay approving an interconnection that uses non-preferred equipment. 
Offshore Services Ltd.

Factory-authorized wind turbine dealer and installer

Block Island, Rhode Island

www.wind-power.com

Henry duPont, owner: offshore@wind-power.com

\section{Background}

Offshore (d.b.a. Lorax Energy Systems) has more than 20 years experience installing residential-sized wind turbines. In the past few years, Offshore has also started to install larger wind turbines.

\section{Distributed Generation Installed}

Offshore has installed approximately 18 systems with $180 \mathrm{~kW}$ of capacity. At the time of writing, it was anticipated that it would install one $250-\mathrm{kW}$ machine and five $50-\mathrm{kW}$ machines in Long Island during the winter of 2002-2003 for LIPA.

\section{Interconnection Experience}

Offshore's projects are typically installed at factories, schools, universities, farms, and water treatment plants. For the most part, state and federal funding drive the favorable economics of these projects. New Jersey, California, and Illinois were recognized by Offshore as states that have some of the most advantageous regulations and incentives for the installation of wind turbines.

In Offshore's experience, utilities are less likely to raise interconnection barriers with smaller wind turbines $(1-3 \mathrm{~kW})$ because it is generally accepted that small wind turbines operating on large grids are unlikely to cause any damage to the grid and are more likely to cause damage to the turbine itself. Utilities are more likely to scrutinize installations using $10-\mathrm{kW}$ and larger turbines.

Most utilities do not require a protective relay for the residential Bergey $10-\mathrm{kW}$ machine because the line-commutated inverter is UL listed. Some do require an additional protective relay (which costs approximately $\$ 5,000$ ). For most faults, the inverter resets itself after a 6minute or 10-minute "wait and see" period. In some cases, the utility protective relay must also be reset, which requires a service call to the utility.

Interconnection can be made easier by involving the utility early in the project. For example, during installation of a $10-\mathrm{kW}$ machine in Gloucester, Massachusetts, the project owner (the Massachusetts Division of Energy Resources) partnered with the local utility. For this installation, a Bergey Wind Power Analog Inverter (designed by Archaval Wind Engineering) was used. Connection was made through the facility distribution panel, which was backfed through a standard dual pole 70-A breaker. At no point during the project did the utility express any concerns about the interconnection engineering. 


\section{Specific Technical Interconnection Issues}

\section{Utilities Requirements of Additional Relays for Wind Turbines}

The interconnection of large wind turbines should present less of a problem than for small generators because utilities do not have to deal with the mystery of the "black box" inverter. Theoretically, a wind turbine should require no protective relays because it is an induction generator; it cannot operate when the grid is not operating. However, Offshore has found that most utilities still require protective relays for larger wind turbine installations. These relays can add $\$ 6,000-\$ 8,000$ to the cost of a $100-\mathrm{kW}$ to $250-\mathrm{kW}$ turbine. In addition, some utilities require that an electrical engineer fill out the application for interconnection, which adds an additional service fee.

\section{Effect of Nuisance Trips on Economics of Projects}

Offshore has frequently found that its turbines go off line because of a fault on some other portion of the feeder that trips the protective relay. When this occurs, Offshore is required to wait until the utility gives it permission to reconnect and resume operation. Offshore would prefer that its switches reset automatically in the case of these nuisance trips so that it does not have to wait for the utility to give approval to resume operation.

Offshore noted that these nuisance trips are a common problem for distributed generators because standardized set points are very tight—only a few percentage points for voltage and even less for frequency. In many regions, these standards continue to be tightened, which subjects distributed generators to frequent disconnections from the grid. These tight set points are especially problematic for wind turbines because the turbines can trip under conditions such as loss of utility power for line maintenance, for which the wind turbine would not operate because it is an induction generator. Because such a relay trip requires a service call to be reset, valuable operational time is lost.

\section{Specific Business/Regulatory Interconnection Issues}

\section{Effect of Standby Charges}

The imposition of standby charges on distributed generators is a concern. Many utilities impose a standby rate on customers when they install distributed generation despite the fact that this is arguably not allowed under the Public Utilities Regulatory Policies Act. At one New England utility, a customer was charged a $\$ 4.60 / \mathrm{kW} /$ month demand charge for peak demand. It was also charged a $\$ 4.60 / \mathrm{kW} / \mathrm{month}$ demand charge for the capacity of the wind turbine. Offshore argues that, in effect, this is double counting, which penalizes the customer because the customer is generating power intermittently. Some utilities exempt generators that are eligible for net metering from these standby charges; however, in many cases, net metering rules only apply to very small generators. 
Pharmaceutical Sourcing Group - Americas

Pharmaceutical operations

Spring House, Pennsylvania

www.jnj.com

Rodney McKenna, facilities engineer: rmckenna@psgus.jnj.com

Bob Barnes, site manager: rbarnes@psgus.jnj.com

\section{Background}

Pharmaceutical Sourcing Group - Americas (PSGA) is owned by Johnson \& Johnson. PSGA integrates Johnson \& Johnson's pharmaceutical operations and quality assurance operations to streamline supply chain management.

\section{Distributed Generation Installed}

PSGA contracted with PowerLight Corp. to install a 75-kW solar PV system with a 100-kVA Xantrex inverter and BP Solar MST 43 modules. Rated output is approximately $60 \mathrm{~kW} \mathrm{AC.}$ The system puts out $208 \mathrm{~V}$ three-phase, which is stepped up to $480 \mathrm{~V}$.

\section{Interconnection Experience}

As a participant in the U.S. Environmental Protection Agency's Green Power Partnership, Johnson \& Johnson has initiated PV projects at several of its companies across the United States. Johnson \& Johnson's corporate headquarters approached PSGA and suggested the installation of a solar PV system at PSGA's Spring House, Pennsylvania, facility. PSGA decided to install the system despite a longer-than-desired payback as a gesture of goodwill toward the local community and in keeping with the corporate mission of good environmental stewardship.

PSGA uses all electricity produced by the system internally and has no provision for selling back to the grid. PowerLight provides both servicing and offsite monitoring for the system. The total installed cost of the system was approximately $\$ 650,000$. Johnson \& Johnson paid about $\$ 300,000$, and the remainder was paid by renewable energy credits and grants.

To interconnect, PSGA filed a two-page application with the local utility, PECO, for parallel operation of a generator exceeding $40 \mathrm{~kW}$. Because the installation was less than $300 \mathrm{~kW}$ and the equipment was pre-certified, the PSGA installation qualified for a simplified approval process with a $\$ 300$ application fee. The time required for approval was approximately 2 months. The utility did not require additional relays or other protective devices and allowed start-up of the system prior to final inspection.

The utility's required interconnection settings included:

- Under voltage: $110 \%$ of nominal line voltage, 0.1 seconds

- Over voltage: $85 \%$ of nominal line voltage, 2 seconds

- Under frequency: $59.5 \mathrm{~Hz}, 10$ cycles

- Over frequency: $60.5 \mathrm{~Hz}, 10$ cycles

- Harmonics: conform to IEEE 519. 
The system has been in operation since May 2002, and although it has not yet been tested for power quality, neither Johnson \& Johnson nor PECO have noted operational difficulties with the system or the interconnection.

\section{Technical Interconnection Issues}

None was noted.

\section{Business/Regulatory Interconnection Issues}

\section{Utility Responsiveness}

There was a minor delay in receiving final approval from the local utility to start up the system. The reason for this delay was unclear. This was resolved after consulting with Johnson \& Johnson's account manager at PECO. 
PowerLight Corp.

PV system integrator

Berkeley, California

www.powerlight.com

Greg Ball, senior engineer: gball@powerlight.com

\section{Background}

PowerLight is a developer of PV projects that has nationwide interconnection experience.

\section{Distributed Generation Installed}

PowerLight's installations average $100 \mathrm{~kW}$ to $200 \mathrm{~kW}$ and are rarely smaller than $30 \mathrm{~kW}$.

\section{Interconnection Experience}

Installations are nearly all three-phase. Xantrex is the principal commercially available inverter used in PowerLight projects, but PowerLight also uses SMA's 2.5-kW unit. All the inverters it uses are UL listed.

PowerLight has found that interconnection still adds unnecessary cost to the overall system cost. Most problems arise from select utilities' position on the level of relay protection required, disconnect switch requirements, and inverter certification.

For PowerLight's purposes, existing state requirements and the protective features inherent in inverters listed to UL 1741 address most of the issues in IEEE 1547. PowerLight anticipates minor changes to the existing standards but believes interconnection experiences should not materially change with the passage of IEEE 1547. Among the issues covered under IEEE 1547, grounding and transformer configuration are rarely a problem because most PowerLight systems tie into customers' existing four-wire service with isolation transformers. Other requirements addressing voltage, frequency, harmonics, flicker, DC injection, and anti-islanding are satisfied by the certified inverters. This is true whether or not the system exports to the grid.

PowerLight believes that California's interconnection process for investor-owned utilities under Rule 21 is generally working. PowerLight has installed more than 50 systems under Rule 21 and has had applications for $100-\mathrm{kW}$ to $500-\mathrm{kW}$ systems approved in as little as 2 weeks. The process benefits from regular Rule 21 meetings held by the California Energy Commission to bring utility and producer representatives together.

Although Rule 21 has made things easier, interconnection in California is still not always consistent or predictable. As in other states, there are often differences of opinion from utility to utility about how the rules should be interpreted, and projects can be substantially delayed solely at the discretion or bias of the individual performing the review. 
PowerLight believes that maintenance and expansion of net metering tariffs for renewable resources is also an important issue. California's extension of net metering tariffs for installations as large as $1 \mathrm{MW}$ has had a significant effect on the viability of solar projects for commercial and industrial customers.

\section{Technical Interconnection Issues}

\section{Interconnection of Systems to Urban Spot Networks}

The greatest remaining technical challenges involve systems interconnected on urban spotnetworks. Although these installations are few, PowerLight finds there is a growing market for rooftop PV systems in urban areas fed by network distribution systems. If installations are allowed at all, they are subject to very site-specific protection requirements to prevent misoperation of utility network protector devices.

\section{Business/Regulatory Interconnection Issues}

Inconsistency of Interconnection Requirements With National Standards

Numerous states and utilities have not revised their aging interconnection policies to allow inverter-based protection (per UL 1741) without supplemental relays. This creates an unnecessary cost and burden. Similarly, New York has adopted an inverter testing criteria that is slightly different from the UL standard. Integrators therefore must go through the additional required tests or install relays that duplicate the inverter's built-in protection.

\section{Difficulty Meeting Interconnection Standards}

In California and elsewhere, utlilities may require 24-hours-a-day, 7-days-a-week access to visible disconnecting switches. Some utilities have policies that require that these switches be located near the utility service entrance or meter. Roof-mounted PV systems are most economic if they tie into existing service panels on the upper floors. The cost to bring power down to a disconnect switch at the ground floor utility tie-in point can be in the tens of thousands. Onerous switch requirements can also be problematic for campus-type installations in which an installation can be blocks from the campus-utility interconnect point. PowerLight believes that these disconnect switch rules are outdated and can be revised to account for today's interconnection technologies without jeopardizing safety. 


\section{Appendix B: Tables Summarizing Interconnection Requirements and Experience}

Table B-1. Selected Technical Distributed Generation Interconnection Requirements of Interviewed Utilities

\begin{tabular}{|c|c|c|c|c|c|c|}
\hline Utility & $\begin{array}{c}\text { Interconnection } \\
\text { Costs }\end{array}$ & $\begin{array}{c}\text { Voltage } \\
\text { Requirements }\end{array}$ & $\begin{array}{c}\text { Frequency } \\
\text { Requirements }\end{array}$ & $\begin{array}{c}\text { Power } \\
\text { Electronics } \\
\text { Requirements }\end{array}$ & Power Factor & $\begin{array}{l}\text { Power Quality } \\
\text { Requirements }\end{array}$ \\
\hline $\begin{array}{l}\text { Alliant } \\
\text { Energy }\end{array}$ & $\begin{array}{l}\text { DG }<200 \mathrm{~kW} \\
\text { pays } \$ 275 \\
\text { engineering study } \\
\text { fee }\end{array}$ & $\begin{array}{l}\text { The relay should be } \\
\text { capable of providing a } \\
\text { trip time in the } 1 / 2-\text { to } \\
2 \text {-second range } \\
\text { Actual voltage and } \\
\text { time delay settings } \\
\text { will be determined on } \\
\text { a case-by-case basis }\end{array}$ & $\begin{array}{l}\text { The relay should be } \\
\text { capable of providing } \\
\text { a trip time in the } 1 / 2- \\
\text { to } 2 \text {-second range } \\
\text { Actual frequency and } \\
\text { time delay settings } \\
\text { will be determined on } \\
\text { a case-by-case } \\
\text { basis. }\end{array}$ & $\begin{array}{l}>200 \mathrm{~kW} \text { : } \\
\text { utility-grade } \\
\text { relays required } \\
<200 \mathrm{~kW} \text { : } \\
\text { industrial- } \\
\text { grade relays } \\
\text { allowed }\end{array}$ & $\begin{array}{l}\text { Depends on } \\
\text { rate class: } \\
\text { Unity }(+/-10 \% \\
\text { for }<200 \mathrm{kVA} \text {, } \\
+/-5 \% \text { for all } \\
\text { others) }\end{array}$ & $\begin{array}{l}\text { IEEE } 519 \text { (cannot } \\
\text { exceed } 3 \% \text { of } \\
\text { fundamental } \\
\text { frequency and } \\
\text { voltage, total } \\
\text { harmonic distortion to } \\
5 \% \text { ) } \\
\text { DC current injection } \\
\text { not specified }\end{array}$ \\
\hline $\begin{array}{l}\text { Anonymous } \\
\text { Note: For } \\
\text { single-phase } \\
\text { up to } 25 \mathrm{~kW} \text { or } \\
\text { three-phase } \\
\text { up to } 300 \mathrm{~kW}\end{array}$ & $\begin{array}{l}\$ 250 \text { to process } \\
\text { application }\end{array}$ & $\begin{array}{l}>50 \%: 10 \text { cycles } \\
50 \% \text { to }>88 \%: 120 \\
\text { cycles } \\
110 \% \text { to }<120 \%: 60 \\
\text { cycles } \\
\geq 120 \%: 6 \text { cycles }\end{array}$ & $\begin{array}{l}\text { For } 10 \mathrm{~kW} \text { or less: } \\
59.3-60.5 \mathrm{~Hz}: 10 \\
\text { cycles } \\
\text { For >10 kW: } \\
\text { >60.5 Hz: } 10 \\
\text { cycles } \\
57-59.3 \mathrm{~Hz} \text { : varied } \\
\text { delay }\end{array}$ & $\begin{array}{l}\text { Certified by } \\
\text { utility based } \\
\text { on past } \\
\text { operating } \\
\text { experience or } \\
\text { must undergo } \\
\text { performance } \\
\text { testing }\end{array}$ & $\mathrm{N} / \mathrm{A}$ & $\begin{array}{l}\text { IEEE } 519 \text { (cannot } \\
\text { exceed } 3 \% \text { of } \\
\text { fundamental } \\
\text { frequency and } \\
\text { voltage, total } \\
\text { harmonic distortion to } \\
5 \% \text { ) } \\
\text { DC current injection } \\
\text { no greater than } 0.5 \% \\
\text { of rated inverter } \\
\text { output }\end{array}$ \\
\hline
\end{tabular}




\begin{tabular}{|c|c|c|c|c|c|c|}
\hline Utility & $\begin{array}{c}\text { Interconnection } \\
\text { Costs }\end{array}$ & Voltage Requirements & $\begin{array}{c}\text { Frequency } \\
\text { Requirements }\end{array}$ & $\begin{array}{c}\text { Power } \\
\text { Electronics } \\
\text { Requirements }\end{array}$ & Power Factor & $\begin{array}{l}\text { Power Quality } \\
\text { Requirements }\end{array}$ \\
\hline $\begin{array}{l}\text { Central } \\
\text { Hudson }\end{array}$ & $\begin{array}{l}\leq 300 \text { kVA: } \$ 350 \\
\text { application fee } \\
>15 \text { kVA: no fee }\end{array}$ & $\begin{array}{l}\text { Up to } 300 \text { kVA: } \\
60 \mathrm{~V}: 6 \text { cycles } \\
>60 \mathrm{~V}-106 \mathrm{~V}: 2 \mathrm{~s} \\
>132 \mathrm{~V}-165 \mathrm{~V}: 2 \mathrm{~s} \\
>165 \mathrm{~V}: 2 \text { cycles }\end{array}$ & $\begin{array}{l}\text { Up to } 300 \mathrm{kVA}: \\
59.3-60.5 \mathrm{~Hz}, 6 \\
\text { cycles }\end{array}$ & $\begin{array}{l}\text { Must pass } \\
\text { type testing by } \\
\text { third-party lab }\end{array}$ & $\begin{array}{l}\text { Up to } 300 \\
\text { kVA: } \\
0.9 \text { leading or } \\
\text { lagging }\end{array}$ & $\begin{array}{l}\text { Up to } 300 \text { kVA: } \\
\text { IEEE } 519 \text { (cannot } \\
\text { exceed } 3 \% \text { of } \\
\text { fundamental } \\
\text { frequency and } \\
\text { voltage, total } \\
\text { harmonic distortion to } \\
5 \% \text { ) } \\
\text { DC current injection } \\
\text { not specified }\end{array}$ \\
\hline Conectiv & $\begin{array}{l}\text { No application } \\
\text { fee up to } 1 \mathrm{MW}\end{array}$ & $\begin{array}{l}\text { Up to } 25 \mathrm{kV} \text { : } \\
>50 \% \text { : } 0.1 \mathrm{~s} \\
50 \% \text { to }>88 \%: 2 \mathrm{~s} \\
>106 \% \text { to }<137 \%: 2 \mathrm{~s} \\
\geq 137 \% \text { : } 0.03 \mathrm{~s} \\
\text { Greater than } 25 \mathrm{kV} \text { : } \\
>50 \% \text { : } 0.1 \mathrm{~s} \\
50 \% \text { to }>88 \% \text { : } \\
0.1-30 \mathrm{~s} \\
>106 \% \text { to }<137 \% \text { : } \\
0.1-30 \mathrm{~s} \\
\quad \geq 137 \% \text { : } 0.03 \mathrm{~s} \\
\text { Non-inverter or } \\
\text { rotational: } \\
<90 \% \text { or }>110 \% \text { : } \\
\text { 0.1-30 s } \\
\geq 137 \% \text { : } 0.1 \mathrm{~s}\end{array}$ & $\begin{array}{l}59.3-60.5 \mathrm{~Hz}: \\
0.1 \mathrm{~s}\end{array}$ & $\begin{array}{l}\text { Review of } \\
\text { design by } \\
\text { utility } \\
\text { Potential to } \\
\text { pre-certify } \\
\text { systems based } \\
\text { on prior } \\
\text { experience }\end{array}$ & $\begin{array}{l}0.85 \text { lagging } \\
\text { or leading }\end{array}$ & $\begin{array}{l}\text { IEEE } 519 \text { (cannot } \\
\text { exceed } 3 \% \text { of } \\
\text { fundamental } \\
\text { frequency and } \\
\text { voltage, total } \\
\text { harmonic distortion to } \\
5 \% \text { ) } \\
\text { DC current injection } \\
\text { no greater than } 0.5 \% \\
\text { of rated inverter } \\
\text { output }\end{array}$ \\
\hline
\end{tabular}




\begin{tabular}{|c|c|c|c|c|c|c|}
\hline Utility & $\begin{array}{c}\text { Interconnection } \\
\text { Costs }\end{array}$ & Voltage Requirements & $\begin{array}{c}\text { Frequency } \\
\text { Requirements }\end{array}$ & $\begin{array}{c}\text { Power } \\
\text { Electronics } \\
\text { Requirements }\end{array}$ & Power Factor & $\begin{array}{l}\text { Power Quality } \\
\text { Requirements }\end{array}$ \\
\hline Idaho Power & & $\begin{array}{l}\text { Less than } 100 \mathrm{kVA}: \\
\quad<60 \mathrm{~V}: 10 \text { cycles } \\
60 \mathrm{~V} \text { to }<106 \mathrm{~V}: 2 \mathrm{~s} \\
>132 \mathrm{~V} \text { to } 144 \mathrm{~V}: 1 \mathrm{~s} \\
>144 \mathrm{~V}: 10 \text { cycles } \\
100 \text { kVA or greater: } \\
\text { Utility discretion }\end{array}$ & $\begin{array}{l}\text { Less than } 100 \\
\text { kVA: } \\
<59.3 \mathrm{~Hz} \text { or } \\
>60.5 \mathrm{~Hz}: 10 \\
\text { cycles } \\
100 \text { kVA or } \\
\text { greater: } \\
\text { Utility discretion }\end{array}$ & $\begin{array}{l}\text { Performance } \\
\text { testing usually } \\
\text { required } \\
\text { Some pre- } \\
\text { certification }\end{array}$ & $\begin{array}{l}0.9 \text { leading or } \\
\text { lagging }\end{array}$ & $\begin{array}{l}\text { IEEE } 519 \text { (cannot } \\
\text { exceed } 3 \% \text { of } \\
\text { fundamental } \\
\text { frequency and } \\
\text { voltage, total } \\
\text { harmonic distortion to } \\
5 \% \text { ) } \\
\text { DC current injection } \\
\text { no greater than } 0.5 \% \\
\text { of rated inverter } \\
\text { output }\end{array}$ \\
\hline LADWP & $\begin{array}{l}\text { Customer pays } \\
\text { cost of } \\
\text { interconnection, } \\
\text { including } \\
\text { extensions or } \\
\text { modifications to } \\
\text { system }\end{array}$ & $\begin{array}{l}<92 \mathrm{~V}: 2 \mathrm{~s} \\
>138 \mathrm{~V}: 2 \mathrm{~s}\end{array}$ & $\begin{array}{l}<57 \mathrm{~Hz}: 2.5 \mathrm{~s} \\
>61 \mathrm{~Hz}: 2.5 \mathrm{~s}\end{array}$ & $\begin{array}{l}\text { UL listing } \\
\text { required for all } \\
\text { interconnection } \\
\text { equipment }\end{array}$ & $\begin{array}{l}<1 \mathrm{MW} \text { : } \\
\text { ave. monthly } \\
\text { on-peak } \\
\text { power not less } \\
\text { than } 85 \% \\
\text { lagging } \\
>1 \mathrm{MW} \text { : } \\
99.5 \% \text { lagging } \\
\text { or } 100.5 \% \\
\text { leading }\end{array}$ & $\begin{array}{l}5 \% \text { of RMS value of } \\
\text { service voltage and } \\
25 \% \text { of current } \\
\text { waveform } \\
\text { DC injection not } \\
\text { noted }\end{array}$ \\
\hline
\end{tabular}




\begin{tabular}{|c|c|c|c|c|c|c|}
\hline Utility & $\begin{array}{l}\text { Interconnection } \\
\text { Costs }\end{array}$ & Voltage Requirements & $\begin{array}{c}\text { Frequency } \\
\text { Requirements }\end{array}$ & $\begin{array}{c}\text { Power } \\
\text { Electronics } \\
\text { Requirements }\end{array}$ & Power Factor & $\begin{array}{l}\text { Power Quality } \\
\text { Requirements }\end{array}$ \\
\hline LIPA & $\mathrm{N} / \mathrm{A}$ & $\begin{array}{l}\text { Up to } 300 \text { kVA: } \\
60 \mathrm{~V}: 6 \text { cycles } \\
>60 \mathrm{~V}-106 \mathrm{~V}: 2 \mathrm{~s} \\
>132 \mathrm{~V}-165 \mathrm{~V}: 2 \mathrm{~s} \\
>165 \mathrm{~V}: 2 \text { cycles } \\
\text { Greater than } 300 \mathrm{kVA}: \\
5 \% \text { of nominal when } \\
\text { operating in parallel } \\
\text { with } 1-\mathrm{s} \text { disconnect if } \\
\text { over } 10 \% \text { of nominal }\end{array}$ & $\begin{array}{l}300 \text { kVA or less: } \\
\text { 59.3-60.5 Hz: } 6 \\
\text { cycles } \\
\text { >300 kVA: } \\
\text { >60.5 Hz: } 0.5 \mathrm{~s} \\
\text { <58.0: } 1 \mathrm{~s}\end{array}$ & $\begin{array}{l}\text { If nontype- } \\
\text { tested: } \\
\text { Must pass } \\
\text { type testing } \\
\text { by third- } \\
\text { party lab } \\
\text { For nontype- } \\
\text { tested } \\
\text { induction } \\
\text { generators up } \\
\text { to } 300 \text { kVA: } \\
\text { Must have } \\
\text { direct } \\
\text { transfer trip } \\
\text { and } \\
\text { potentially } \\
\text { SCADA }\end{array}$ & $\begin{array}{l}300 \text { kVA or } \\
\text { less: } \\
0.9 \text { leading } \\
\text { or lagging } \\
\text { For >300 kVA: } \\
\text { Between } 0.9 \\
\text { and } 1 \\
\text { leading or } \\
\text { lagging }\end{array}$ & $\begin{array}{l}300 \text { kVA or less: } \\
\text { IEEE } 519 \text { (cannot } \\
\text { exceed } 3 \% \text { of funda- } \\
\text { mental frequency and } \\
\text { voltage, total harmon- } \\
\text { ic distortion to } 5 \% \text { ) } \\
\text { For }>300 \mathrm{kVA} \text { : cannot } \\
\text { exceed } 5 \% \text { of } \\
\text { fundamental } 60 \mathrm{~Hz} \text { or } \\
\text { current waveform } \\
\text { A single waveform } \\
\text { cannot exceed } 3 \% \text { of } \\
\text { fundamental } \\
\text { frequency } \\
\text { DC current injection } \\
\text { not specified }\end{array}$ \\
\hline PG\&E & $\begin{array}{l}\$ 800 \text { initial } \\
\text { review fee (Rule } \\
21) ; \$ 600 \\
\text { supplemental } \\
\text { review fee }\end{array}$ & $\begin{array}{l}<60 \mathrm{~V}: 10 \text { cycles } \\
60 \mathrm{~V} \text { to }<106 \mathrm{~V}: 120 \\
\text { cycles } \\
>132 \mathrm{~V} \text { to } 165 \mathrm{~V}: 120 \\
\text { cycles ( } 30 \text { cycles for } \\
\text { installations greater than } \\
11 \mathrm{kVA} \text { ) } \\
>165 \mathrm{~V}: 6 \text { cycles }\end{array}$ & $\begin{array}{l}\text { For <11 kVA: } \\
59.3-60.5 \mathrm{~Hz} \text {, } \\
10 \text { cycles } \\
\text { For >11 kVA: } \\
\text { utility may } \\
\text { require } \\
\text { adjustable } \\
\text { operating } \\
\text { frequency }\end{array}$ & $\begin{array}{l}\text { Requires UL } \\
\text { certification; } \\
\text { non-UL- } \\
\text { certified } \\
\text { equipment } \\
\text { must be } \\
\text { certified by } \\
\text { national } \\
\text { testing lab }\end{array}$ & $\begin{array}{l}0.9 \text { leading or } \\
\text { lagging }\end{array}$ & $\begin{array}{l}\text { IEEE } 519 \text { (cannot } \\
\text { exceed } 3 \% \text { of } \\
\text { fundamental } \\
\text { frequency and } \\
\text { voltage, total } \\
\text { harmonic distortion to } \\
5 \% \text { ) } \\
\text { DC current injection } \\
\text { no greater than } 0.5 \% \\
\text { of rated inverter } \\
\text { output }\end{array}$ \\
\hline
\end{tabular}




\begin{tabular}{|c|c|c|c|c|c|c|}
\hline Utility & $\begin{array}{c}\text { Interconnection } \\
\text { Costs }\end{array}$ & Voltage Requirements & $\begin{array}{c}\text { Frequency } \\
\text { Requirements }\end{array}$ & $\begin{array}{c}\text { Power } \\
\text { Electronics } \\
\text { Requirements }\end{array}$ & Power Factor & $\begin{array}{l}\text { Power Quality } \\
\text { Requirements }\end{array}$ \\
\hline SDG\&E & $\begin{array}{l}\$ 800 \text { initial } \\
\text { review fee (Rule } \\
21) ; \$ 600 \\
\text { supplemental } \\
\text { review fee }\end{array}$ & $\begin{array}{l}<60 \mathrm{~V}: 10 \text { cycles } \\
60 \mathrm{~V} \text { to }<106 \mathrm{~V}: 120 \\
\text { cycles } \\
>132 \mathrm{~V} \text { to } 165 \mathrm{~V}: 120 \\
\text { cycles ( } 30 \text { cycles for } \\
\text { installations greater than } \\
11 \mathrm{kVA} \text { ) } \\
>165 \mathrm{~V}: 6 \text { cycles }\end{array}$ & $\begin{array}{l}\text { For <11 kVA: } \\
59.3-60.5 \mathrm{~Hz} \text {, } \\
10 \text { cycles } \\
\text { For >11 kVA: } \\
\text { Utility may } \\
\text { require } \\
\text { adjustable } \\
\text { operating } \\
\text { frequency }\end{array}$ & $\begin{array}{l}\text { Certification by } \\
\text { utility }\end{array}$ & $\begin{array}{l}0.9 \text { leading or } \\
\text { lagging }\end{array}$ & $\begin{array}{l}\text { IEEE } 519 \text { (cannot } \\
\text { exceed } 3 \% \text { of } \\
\text { fundamental } \\
\text { frequency and } \\
\text { voltage, total } \\
\text { harmonic distortion to } \\
5 \% \text { ) } \\
\text { DC current injection } \\
\text { no greater than } 0.5 \% \\
\text { of rated inverter } \\
\text { output }\end{array}$ \\
\hline SCE & $\begin{array}{l}\$ 800 \text { initial } \\
\text { review fee (Rule } \\
21) ; \$ 600 \\
\text { supplemental } \\
\text { review fee }\end{array}$ & $\begin{array}{l}<60 \text { volts: } 10 \text { cycles } \\
60 \text { volts to < } 106 \text { volts: } \\
120 \text { cycles } \\
>132 \text { volts to } 165 \text { volts: } \\
120 \text { cycles ( } 30 \text { cycles for } \\
\text { installations greater than } \\
11 \text { kVA) } \\
>165 \text { volts: } 6 \text { cycles }\end{array}$ & $\begin{array}{l}\text { For <11 kVA: } \\
59.3-60.5 \mathrm{~Hz} \text {, } \\
10 \text { cycles } \\
\text { For >11 kVA: } \\
\text { Utility may } \\
\text { require } \\
\text { adjustable } \\
\text { operating } \\
\text { frequency }\end{array}$ & $\begin{array}{l}\text { Requires UL } \\
\text { certification; } \\
\text { non-UL-certified } \\
\text { equipment must } \\
\text { be certified by } \\
\text { national testing } \\
\text { lab }\end{array}$ & $\begin{array}{l}0.9 \text { leading or } \\
\text { lagging }\end{array}$ & $\begin{array}{l}\text { IEEE } 519 \text { (cannot } \\
\text { exceed } 3 \% \text { of } \\
\text { fundamental } \\
\text { frequency and } \\
\text { voltage, total } \\
\text { harmonic distortion to } \\
5 \% \text { ) } \\
\text { DC current injection } \\
\text { no greater than } 0.5 \% \\
\text { of rated inverter } \\
\text { output }\end{array}$ \\
\hline
\end{tabular}


Table B-2. Major Technical, Business, and Regulatory Issues Encountered by Utilities During Distributed Generation Interconnection

\begin{tabular}{|c|c|c|c|c|c|}
\hline Utility & Islanding Issues & $\begin{array}{c}\text { Power Electronics } \\
\text { Issues }\end{array}$ & $\begin{array}{l}\text { Power Quality } \\
\text { Issues }\end{array}$ & $\begin{array}{l}\text { Other Specific } \\
\text { Technical Issues }\end{array}$ & $\begin{array}{c}\text { Specific } \\
\text { Business/Regulatory } \\
\text { Issues }\end{array}$ \\
\hline Alliant & None noted & None noted & $\begin{array}{l}\text { Control of distributed } \\
\text { generation voltage } \\
\text { and frequency when } \\
\text { disconnected }\end{array}$ & $\begin{array}{l}\text { Nuisance trips } \\
\text { disconnect } \\
\text { distributed } \\
\text { generation from } \\
\text { system }\end{array}$ & None noted \\
\hline Anonymous & $\begin{array}{l}\text { Safety of distributed } \\
\text { generation on the } \\
\text { system }\end{array}$ & None noted & None noted & None noted & None noted \\
\hline Central Hudson & None noted & $\begin{array}{l}\text { Pre-certification of } \\
\text { power electronics } \\
\text { can create problems }\end{array}$ & None noted & None noted & $\begin{array}{l}\text { Importance of standard } \\
\text { market design }\end{array}$ \\
\hline Conectiv & None noted & None noted & None noted & $\begin{array}{ll}\text { - } & \text { Distributed } \\
\text { generation trips } \\
\text { during } \\
\text { momentary } \\
\text { interruptions } \\
\text { - } & \text { Available } \\
\text { short circuit } \\
\text { too high for } \\
\text { customer } \\
\text { switchgear }\end{array}$ & None noted \\
\hline Idaho Power & $\begin{array}{l}\text { Ensuring safety } \\
\text { of linemen and } \\
\text { the grid } \\
\text { - Islanding }\end{array}$ & None noted & $\begin{array}{ll}\text { - } & \text { Voltage } \\
\text { regulation } \\
\text { - } \\
\text { Voltage at } \\
\text { system startup } \\
\text { DG impedes } \\
\text { ability to maintain } \\
\text { voltage on grid }\end{array}$ & None noted & $\begin{array}{l}\text { Customers require } \\
\text { education on } \\
\text { interconnection process }\end{array}$ \\
\hline
\end{tabular}




\begin{tabular}{|c|c|c|c|c|c|}
\hline Utility & Islanding Issues & $\begin{array}{l}\text { Power Electronics } \\
\text { Issues }\end{array}$ & $\begin{array}{l}\text { Power Quality } \\
\text { Issues }\end{array}$ & $\begin{array}{l}\text { Other Specific } \\
\text { Technical Issues }\end{array}$ & $\begin{array}{l}\text { Specific } \\
\text { Business/Regulator } \\
\text { y Issues }\end{array}$ \\
\hline LADWP & $\begin{array}{l}\text { Ensuring safety of } \\
\text { linemen and } \\
\text { customers }\end{array}$ & None noted & None noted & $\begin{array}{l}\text { Understanding effect } \\
\text { of base load } \\
\text { penetration of } \\
\text { distributed generation } \\
\text { on the grid }\end{array}$ & $\begin{array}{l}\text { Capital cost recovery } \\
\text { for utilities }\end{array}$ \\
\hline LIPA & $\begin{array}{l}\text { Local work methods } \\
\text { sometimes require } \\
\text { additional protection } \\
\text { schemes }\end{array}$ & None noted & None noted & $\begin{array}{l}\text { - } \quad \text { Effect of } \\
\text { distributed } \\
\text { generation on } \\
\text { secondary } \\
\text { networks } \\
\text { Effect of } \\
\text { distributed } \\
\text { generation } \\
\text { penetration on } \\
\text { the grid }\end{array}$ & None noted \\
\hline PG\&E & Islanding & None noted & $\begin{array}{l}\text { Effect of distributed } \\
\text { generation on power } \\
\text { quality }\end{array}$ & $\begin{array}{l}\text { Effect of distributed } \\
\text { generation on } \\
\text { networks }\end{array}$ & $\begin{array}{l}\text { Educating } \\
\text { stakeholders on } \\
\text { distributed generation }\end{array}$ \\
\hline $\begin{array}{l}\text { SDG\&E } \\
\text { SCE }\end{array}$ & $\begin{array}{l}\text { None noted } \\
\text { None noted }\end{array}$ & $\begin{array}{l}\text { None noted } \\
\text { None noted }\end{array}$ & $\begin{array}{l}\text { None noted } \\
\text { None noted }\end{array}$ & $\begin{array}{l}\text { None noted } \\
\text { Complexity of grid } \\
\text { makes plug-and-play } \\
\text { interconnection } \\
\text { difficult }\end{array}$ & $\begin{array}{l}\text { None noted } \\
\text { - } \quad \text { Education of } \\
\text { customers } \\
\text { regarding } \\
\text { distributed } \\
\text { generation issues } \\
\text { Mandated } \\
\text { application fees } \\
\text { do not cover } \\
\text { costs }\end{array}$ \\
\hline
\end{tabular}


Table B-3. Major Technical, Business, and Regulatory Issues Encountered by Customers and Manufactures During Distributed Generation Interconnection

\begin{tabular}{|c|c|c|c|c|c|}
\hline $\begin{array}{l}\text { Customerl } \\
\text { Manufacturer }\end{array}$ & Islanding Issues & $\begin{array}{c}\text { Power Electronics } \\
\text { Issues }\end{array}$ & $\begin{array}{c}\text { Power Quality } \\
\text { Issues }\end{array}$ & $\begin{array}{l}\text { Other Specific } \\
\text { Technical Issues }\end{array}$ & $\begin{array}{c}\text { Specific } \\
\text { Business/Regulatory } \\
\text { Issues }\end{array}$ \\
\hline $\begin{array}{l}\text { Alternate } \\
\text { Energy }\end{array}$ & None noted & None noted & None noted & None noted & $\begin{array}{l}\text { No third-party inspector } \\
\text { certification }\end{array}$ \\
\hline $\begin{array}{l}\text { Bergey } \\
\text { Windpower }\end{array}$ & $\begin{array}{l}\text { Anti-islanding } \\
\text { requirements not } \\
\text { based on real-world } \\
\text { situations }\end{array}$ & None noted & $\begin{array}{l}\text { Loads and utilities not } \\
\text { required to comply } \\
\text { with IEEE } 519\end{array}$ & None noted & $\begin{array}{l}\text { State interconnection } \\
\text { standards not } \\
\text { consistent with national } \\
\text { standards } \\
\text { - Lack of consistency } \\
\text { across utilities subject } \\
\text { to the same } \\
\text { interconnection } \\
\text { standard } \\
\text { - Utilities use safety to } \\
\text { mask anti- } \\
\text { competitiveness }\end{array}$ \\
\hline BP Solar & $\begin{array}{l}\text { Utility safety } \\
\text { concerns }\end{array}$ & None noted & None noted & None noted & $\begin{array}{l}\text { Education of utility } \\
\text { employees } \\
\text { - Inconsistency of state } \\
\text { and national } \\
\text { interconnection } \\
\text { standards }\end{array}$ \\
\hline $\begin{array}{l}\text { Capstone } \\
\text { Turbine }\end{array}$ & $\begin{array}{l}\text { Anti-islanding for } \\
\text { multi-unit } \\
\text { installations }\end{array}$ & $\begin{array}{l}\text { Standardized on-site } \\
\text { performance testing of } \\
\text { power electronics }\end{array}$ & None noted & $\begin{array}{l}\text { Effect of distributed } \\
\text { generation } \\
\text { proliferation on } \\
\text { feeders }\end{array}$ & $\begin{array}{ll}\text { - } & \text { Tariffs } \\
\text { - } & \text { Need for statewide } \\
\text { interconnection } \\
\text { standards } \\
\text { - } \\
\text { Education of protection } \\
\text { engineers }\end{array}$ \\
\hline
\end{tabular}




\begin{tabular}{|c|c|c|c|c|c|}
\hline $\begin{array}{l}\text { Customerl } \\
\text { Manufacturer }\end{array}$ & Islanding Issues & $\begin{array}{c}\text { Power Electronics } \\
\text { Issues }\end{array}$ & $\begin{array}{c}\text { Power Quality } \\
\text { Issues }\end{array}$ & $\begin{array}{l}\text { Other Specific } \\
\text { Technical Issues }\end{array}$ & $\begin{array}{c}\text { Specific } \\
\text { Business/Regulatory } \\
\text { Issues }\end{array}$ \\
\hline Cordis & None noted & None noted & None noted & None noted & $\begin{array}{l}\text { Responsiveness of the } \\
\text { utility }\end{array}$ \\
\hline $\begin{array}{l}\text { Cummins } \\
\text { Engine }\end{array}$ & $\begin{array}{l}\text { Anti-islanding } \\
\text { standards } \\
\text { unrealistic }\end{array}$ & $\begin{array}{l}\text { Finding proper settings } \\
\text { for protection devices }\end{array}$ & None noted & $\begin{array}{l}\text { Nuisance trips } \\
\text { caused by grid }\end{array}$ & $\begin{array}{l}\text { - Interpretation of } \\
\text { interconnection rules } \\
\text { vary by utility } \\
\text { - State interconnection } \\
\text { rules leave too much } \\
\text { open to interpretation }\end{array}$ \\
\hline Hess Microgen & None noted & $\begin{array}{l}\text { Use of UL } 1741 \text { as a } \\
\text { pre-certification } \\
\text { standard for rotational } \\
\text { generators }\end{array}$ & None noted & $\begin{array}{l}\text { Utilities use } \\
\text { large generator } \\
\text { interconnection } \\
\text { standards for } \\
\text { small } \\
\text { generators } \\
\text { Nuisance trips } \\
\text { caused by the } \\
\text { grid } \\
\text { Direct transfer } \\
\text { trip erroneously } \\
\text { required by } \\
\text { utilities }\end{array}$ & $\begin{array}{l}\text { Standby charges and exit } \\
\text { fees }\end{array}$ \\
\hline
\end{tabular}




\begin{tabular}{|c|c|c|c|c|c|}
\hline $\begin{array}{l}\text { Customerl } \\
\text { Manufacturer }\end{array}$ & Islanding Issues & $\begin{array}{c}\text { Power Electronics } \\
\text { Issues }\end{array}$ & $\begin{array}{l}\text { Power Quality } \\
\text { Issues }\end{array}$ & $\begin{array}{l}\text { Other Specific } \\
\text { Technical Issues }\end{array}$ & $\begin{array}{c}\text { Specific } \\
\text { Business/Regulatory } \\
\text { Issues }\end{array}$ \\
\hline Ingersoll-Rand & None noted & None noted & None noted & $\begin{array}{l}\text { Utilities requiring } \\
\text { installation of } \\
\text { capacitor banks }\end{array}$ & $\begin{array}{l}\text { - Utility charges affect } \\
\text { project economics } \\
\text { - Interconnection } \\
\text { standards and } \\
\text { requirements vary } \\
\text { among utilities } \\
\text { - Utility interconnection } \\
\text { contacts difficult to } \\
\text { identify/lack } \\
\text { knowledge }\end{array}$ \\
\hline $\begin{array}{l}\text { Offshore } \\
\text { Services Ltd. }\end{array}$ & $\begin{array}{l}\text { Utilities require } \\
\text { unnecessary relays } \\
\text { for wind turbines }\end{array}$ & None noted & None noted & $\begin{array}{l}\text { Nuisance trips affect } \\
\text { project economics }\end{array}$ & Effect of standby charges \\
\hline PSGA & None noted & None noted & None noted & None noted & Utility responsiveness \\
\hline PowerLight & None noted & None noted & None noted & $\begin{array}{l}\text { Interconnect of } \\
\text { system to urban spot } \\
\text { networks }\end{array}$ & $\begin{array}{l}\text { - Inconsistency of state } \\
\text { and national } \\
\text { interconnection } \\
\text { standards } \\
\text { - Interconnect } \\
\text { standards difficult to } \\
\text { meet }\end{array}$ \\
\hline
\end{tabular}




\section{Appendix C: Interviews Not Included in Case Write-Ups}

A number of interviews were conducted but not included in the final report. These interviews were not included for the reasons detailed in the following table.

Table C- 1. Interviews Not Included in Case Write-Ups

\begin{tabular}{|c|c|c|}
\hline Company & Interviewee(s) & $\begin{array}{c}\text { Reason Interview Was Not Included in } \\
\text { Final Report }\end{array}$ \\
\hline Commonwealth & John Bettler and Robert & Unable to verify final write-up of interview \\
\hline Edison & Peterson & with interviewees \\
\hline Consultant & Brad Johnson & Background interview \\
\hline Consultant & Larry Speilvogel & Background interview \\
\hline $\begin{array}{l}\text { Edison Electric } \\
\text { Institute }\end{array}$ & Louis Harris & Background interview \\
\hline $\begin{array}{l}\text { Island Energy } \\
\text { Solutions }\end{array}$ & Keith Cronin & $\begin{array}{l}\text { Insufficient information gathered in interview } \\
\text { to merit write-up }\end{array}$ \\
\hline $\begin{array}{l}\text { Kamuela } \\
\text { Consulting }\end{array}$ & Orville Thompson & Background interview \\
\hline Services & & \\
\hline $\begin{array}{l}\text { Off-Peak/Elite } \\
\text { Energy Group LLC }\end{array}$ & Ray Starling & $\begin{array}{l}\text { Chose not to participate in the study } \\
\text { following interview }\end{array}$ \\
\hline PJM & Kevin Komara & Background interview \\
\hline Real Energy & Robin Luke & $\begin{array}{l}\text { Insufficient information gathered in interview } \\
\text { to merit write-up }\end{array}$ \\
\hline $\begin{array}{l}\text { Sacramento } \\
\text { Municipal Utility } \\
\text { District }\end{array}$ & $\begin{array}{l}\text { Bud Beebe, Dave Collier, } \\
\text { and Vince Schwent }\end{array}$ & $\begin{array}{l}\text { Unable to verify final write-up of interview } \\
\text { with interviewees }\end{array}$ \\
\hline $\begin{array}{l}\text { Schott Applied } \\
\text { Power }\end{array}$ & Tom Starrs & $\begin{array}{l}\text { Unable to verify final write-up of interview } \\
\text { with interviewee }\end{array}$ \\
\hline Select Energy & $\begin{array}{l}\text { Charles Brickley, } \\
\text { Stephen Bruno, and Marc } \\
\text { Hanks }\end{array}$ & $\begin{array}{l}\text { Insufficient information gathered in interview } \\
\text { to merit write-up }\end{array}$ \\
\hline $\begin{array}{l}\text { Sunline Transit } \\
\text { Agency }\end{array}$ & $\begin{array}{l}\text { Bill Clapper, William } \\
\text { Maier, and Tommy } \\
\text { Edwards }\end{array}$ & $\begin{array}{l}\text { Chose not to participate in the study } \\
\text { following interview }\end{array}$ \\
\hline Verizon & Jon Chestnut & $\begin{array}{l}\text { Chose not to participate in the study } \\
\text { following interview }\end{array}$ \\
\hline
\end{tabular}




\section{Appendix D: Questionnaires for Interviews}

\section{D.1 Interconnection Questionnaire - DER Manufacturers/Customers/Owners}

\section{General Information}

Interview with:

Interviewers:

Interview date:

Interview location:

\section{Technology Description}

Typical owner type:

Residential Commercial Industrial Institutional Public Safety

Description of generation and/or storage technology(ies) installed:

Technology manufacturer(s):

Installation size $(\mathrm{kW})$; storage capacity $(\mathrm{kWh})$; etc.:

Voltage:

Purpose(s) of installation (economics - operating or capital costs, power quality, reliability, peaking, CHP, green power, etc.)

Description of controls, inverters, filters, or other power electronics installed:

Interconnection with the grid (where it is interconnected, voltage at interconnection point):

\section{Project Design, Approval, Installation}

Who suggested the project (own staff, utility, ESCo, consultant)?

Who designed the project? What alternatives where considered, including the option of doing nothing?

What studies and assessments were done and by whom?

Describe the approval or permitting process:

What approvals were needed (internal, utility, building inspector, EPA/emissions, etc.)? What standards or guidelines did you have to meet?

\section{Procedure for Interconnection}

How did the utility queuing system work? Were there special provisions for DER?

Who performed the interconnection?

Was any special testing required? If so, who performed the testing? 
Was any special hardware required? Who required it? Utility? Regulator?

Who performed inspections (local inspector, utility, other)?

[Note - Inspections and approvals are needed for more than just interconnection - see \#3.]

What regulations or guidelines did the inspectors use?

Describe the feeders that the DG is on. How heavily loaded is the substation and feeder? Does the DG provide any relief?

Do you have a net metering agreement with the utility? If so, at what price do you sell power (peak, off-peak, average, real-time, etc.)? Does your utility rate include a demand charge? How does the operation of the DG affect this?

Cost to resolve interconnection issues:

- Special interconnection equipment costs:

- Engineering studies required and costs:

- Other costs:

\section{Operating Experience}

Who operates the DG unit?

Has the interconnection operated successfully?

If not, what problems have occurred? Describe specific incidents.

- Voltage regulation/disturbances/fluctuations/flicker

- Grounding

- Synchronization

- Islanding/isolation/disconnection for faults

- Frequency regulation/disturbances

- Surge

- Feeder reclosing

- DC injection

- Harmonics

- Immunity protection

How have these problems been resolved?

Has the performance of the installation matched forecast benefits? For the owner? For the utility (if applicable)? 
Does the installation include monitoring equipment? What type? Is operational data collected? What data or other information do you receive on the performance of the DG? How often do you receive it? Who collects it?

Do you plan to install additional DG? Expand or change the operating mode of your DG?

Looking back, what would you do differently in your design, construction, permitting, and/or operation of this DG project? 


\section{D.2 Interconnection Questionnaire - Utilities}

\section{General Information}

Interview with:

Interviewers:

Interview date:

Interview location:

\section{Technology Description}

Types of generation owners (building/facility owner, tenant, utility, ESCo, etc.):

Typical owner types:

Residential Commercial Industrial Institutional Public Safety

Primary use of DER facilities on grid:

Description of typical generation and/or storage technology(ies) installed on utility grid (microturbine, PV, CHP, fuel cells, other):

Typical installation size $(\mathrm{kW})$; storage capacity $(\mathrm{kWh})$; etc.:

Voltage:

Purpose(s) of most DG installations on grid (economics - operating or capital costs, power quality, reliability, peaking, CHP, green power, etc.). Does purpose vary by technology installed?

Description of typical controls, inverters, filters, or other power electronics installed. Are they required by you?

Types of interconnection with the grid (where it is typically interconnected, typical voltage at interconnection point):

\section{Project Design, Approval, Installation}

Who suggests a typical project (own staff, utility, ESCo, consultant)?

Who designs the project? What alternatives are considered, including the option of doing nothing?

What studies and assessments are done and by whom?

Describe the approval or permitting process. What approvals are needed (internal, utility, building inspector, EPA/emissions, etc.)? What standards or guidelines does the DER owner have to meet? 


\section{Procedure for Interconnection}

How does the queuing system work? Are there special provisions for DER?

Who performs DER interconnections with your system?

Is any special testing required? If so, who performs the testing?

Is any special hardware required? Who requires it? Utility? Regulator?

What interconnection standard do you use? CEC Rule 21? P1547? State? Other?

Who performs inspections (local inspector, utility, other)?

[Note - Inspections and approvals are needed for more than just interconnection - see \#3.]

What regulations or guidelines do the inspectors use?

Does DG provide any relief to heavily loaded substations and feeders?

Do you have a net metering agreement available to customers? If so, at what price do you buy power (peak, off-peak, average, real-time, etc.)? Does your utility rate include a demand charge? How does the operation of the DG affect this?

Typical cost to resolve interconnection issues:

- Special interconnection equipment costs:

- Engineering studies required and costs:

- Other costs:

\section{Operating Experience}

Who operates DG units on your grid?

Do the interconnections with customer DG typically operate successfully?

If not, what problems have occurred? Describe specific incidents.

- Voltage regulation/disturbances/fluctuations/flicker

- Grounding

- Synchronization

- Islanding/isolation/disconnection for faults

- Frequency regulation/disturbances

- Surge

- Feeder reclosing

- DC injection

- Harmonics

- Immunity protection 
How have these problems been resolved?

Has the performance of the installation matched forecast benefits? For the owner? For the utility (if applicable)?

Do DG installations typically include monitoring equipment? What type? Is operational data collected? What data or other information do you receive on the performance of the DG? How often do you receive it? Who collects it? 


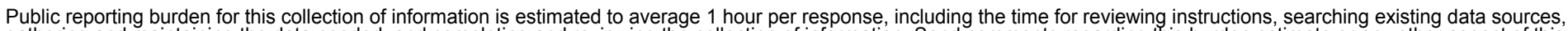

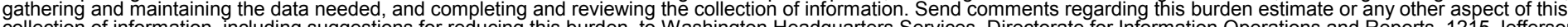

Davis Highway, Suite 1204, Arlington, VA 22202-4302, and to the Office of Management and Budget, Paperwork Reduction Project (0704-0188), Washington, DC 20503.
1. AGENCY USE ONLY (Leave blank)
2. REPORT DATE
September 2003
3. REPORT TYPE AND DATES COVERED
Subcontract report

4. TITLE AND SUBTITLE

Current Solutions: Recent Experience in Interconnecting Distributed Energy Resources

5. FUNDING NUMBERS

6. $\mathrm{AUTHOR}(\mathrm{S})$

M. Johnson

DP03.1001

7. PERFORMING ORGANIZATION NAME(S) AND ADDRESS(ES)

Sentech Inc.

8. PERFORMING ORGANIZATION REPORT NUMBER

4733 Bethesda Ave, Ste. 608

Bethesda, MD 20814

9. SPONSORING/MONITORING AGENCY NAME(S) AND ADDRESS(ES)

National Renewable Energy Laboratory

1617 Cole Blvd.

Golden, CO 80401-3393

10. SPONSORING/MONITORING
AGENCY REPORT NUMBER

NREL/SR-560-34864

11. SUPPLEMENTARY NOTES

NREL Technical Monitor: Holly Thomas

12a. DISTRIBUTION/AVAILABILITY STATEMENT

National Technical Information Service

12b. DISTRIBUTION CODE

U.S. Department of Commerce

5285 Port Royal Road

Springfield, VA 22161

13. ABSTRACT (Maximum 200 words)

This report catalogues selected real-world technical experiences of utilities and customers that have interconnected distributed energy assets with the electric grid. This study was initiated to assess the actual technical practices for interconnecting distributed generation and had a particular focus on the technical issues covered under the Institute of Electrical and Electronics Engineers (IEEE) $1547^{\mathrm{TM}}$ Standard for Interconnecting Distributed Resources With Electric Power Systems.

14. SUBJECT TERMS

interconnection; distributed energy resources; distributed power; distributed generation;

DER; IEEE 1547; standards; Distribution and Interconnection R\&D; National

Renewable Energy Laboratory; NREL

17. SECURITY CLASSIFICATION OF REPORT Unclassified
18. SECURITY CLASSIFICATION OF THIS PAGE Unclassified
19. SECURITY CLASSIFICATION OF ABSTRACT

Unclassified
15. NUMBER OF PAGES

16. PRICE CODE

20. LIMITATION OF ABSTRACT

UL 